\title{
Development of Femtosecond Laser-Engineered $\beta$-Tricalcium Phosphate $(\beta-$ TCP) Biomimetic Templates for Orthopaedic Tissue Engineering
}

\author{
Albena Daskalova ${ }^{1, *(\mathbb{D})}$, Liliya Angelova ${ }^{1}\left(\mathbb{D}\right.$, Anton Trifonov ${ }^{2}$, Marie Lasgorceix ${ }^{3,4,5}{ }^{\circledR}$, Stephane Hocquet ${ }^{4,5,6}$, \\ Mendy Minne ${ }^{7}$, Heidi Declercq ${ }^{7}$, Anne Leriche ${ }^{3,4,5}$, Dante Aceti ${ }^{1}{ }^{1}$ and Ivan Buchvarov ${ }^{2}$ \\ 1 Institute of Electronics, Bulgarian Academy of Sciences, 1784 Sofia, Bulgaria; lily1986@abv.bg (L.A.); \\ acetidm@gmail.com (D.A.) \\ 2 Faculty of Physics, St. Kliment Ohridski University of Sofia, 1164 Sofia, Bulgaria; \\ a.trifonov@phys.uni-sofia.bg (A.T.); ivan.buchvarov@phys.uni-sofia.bg (I.B.) \\ 3 Laboratoire des Matériaux Céramiques et Procédés Associés, Université Polytechnique Hauts-de-France, \\ 59600 Maubeuge, France; Marie.Lasgorceix@uphf.fr (M.L.); aleriche@univ-valenciennes.fr (A.L.) \\ 4 GIS TechCera Mons, Groupement D'intérêt Transfontalier sur la Céramique, 7000 Mons, Belgium; \\ s.hocquet@bcrc.be \\ 5 GIS TechCera Maubeuge, Groupement D'intérêt Transfontalier sur la Céramique, 59600 Maubeuge, France \\ 6 Belgian Ceramic Research Centre (member of EMRA) 4, Avenue Gouverneur Cornez, 7000 Mons, Belgium \\ check for \\ updates \\ Citation: Daskalova, A.; \\ 7 Tissue Engineering Lab, Department of Development and Regeneration, KU Leuven, E Sabbelaan 53, \\ 8500 Kortrijk, Belgium; mendy.minne@kuleuven.be (M.M.); heidi.declercq1@kuleuven.be (H.D.) \\ * Correspondence: albdaskalova@gmail.com
}

Angelova, L.; Trifonov, A.;

Lasgorceix, M.; Hocquet, S.;

Minne, M.; Declercq, H.; Leriche, A.; Aceti, D.; Buchvarov, I. Development of Femtosecond Laser-Engineered $\beta$-Tricalcium Phosphate ( $\beta$-TCP) Biomimetic Templates for Orthopaedic Tissue Engineering. Appl. Sci. 2021, 11, 2565. https://doi.org/10.3390/ app11062565

Academic Editors: Lapo Governi and Giuseppe Perale

Received: 1 February 2021

Accepted: 9 March 2021

Published: 12 March 2021

Publisher's Note: MDPI stays neutral with regard to jurisdictional claims in published maps and institutional affiliations.

Copyright: (c) 2021 by the authors. Licensee MDPI, Basel, Switzerland. This article is an open access article distributed under the terms and conditions of the Creative Commons Attribution (CC BY) license (https:/ / creativecommons.org/licenses/by/ $4.0 /)$.

\begin{abstract}
Reconstruction of bone tissue defects is a problematic area of the modern world. Temporary "platforms" of various materials for improving cell adhesion and proliferation have been extensively researched in recent decades. $\beta$-tricalcium phosphate $(\beta-\mathrm{TCP})$ is a suitable biocompatible, biodegradable material used for bone regeneration. The creation of scaffolds with specifically designed surface structures will enable bone engineering applications that require navigated cell proliferation on a substrate with pre-set geometric limits. In this study, an innovative laser-based technique for surface modification was applied to improve the morphological properties of the surface of $\beta$-TCP pellets for proper cell surface environment creation. The obtained topographies with diverse processing parameters were compared. Homogenous microgroove structures, less than $100 \mu \mathrm{m}$, without the onset of melting and crack formation, were produced. The contribution from the accumulation effect of a diverse number of laser pulses $(\mathrm{N}=1-100)$ on the final structure dimensions was examined. The microstructured scaffolds were investigated by confocal laser scanning microscopy (CLSM), scanning electron microscopy (SEM), energy-dispersive X-ray spectroscopy (EDX), Fourier-transform infrared spectroscopy (FTIR), and X-ray diffraction (XRD) analyses. We studied the effect of the patterned surface of the material on the mouse calvaria osteoblast (MC3T3) cells' viability and cytotoxicity from 1 to 7 days. The results indicated that cell behavior was affected by microscale dimensions of the surface.
\end{abstract}

Keywords: $\beta$-tricalcium phosphate; bioceramics; femtosecond laser processing; bone tissue engineering; temporal scaffolds

\section{Introduction}

The Earth's population is growing older with each passing year. According to data from World Population Prospects: the 2019 Revision, by 2050, 16\% of the people in the world will be over age 65 [1]. As a result, bone fractures and pathologies are emerging as one of the major problems confronting modern medicine. In their elaborate review, Scheinpflung et al. [2] explain in detail bone structure, its vital role in the normal functioning of the body, and the innovative approaches that have emerged in recent years to deal with 
bone tissue malfunctions. The traditional treatment includes transplantation of own or foreign bone tissue or artificial implants (most commonly made of titanium or stainless steel alloys) [2]. Unfortunately, current treatment options hide many negative consequences for the recipient, such as the risk of infection, high immune response, and poor healing of bone tissue [3]. The attractive interdisciplinary field of regenerative medicine offers alternative options for reconstruction of such damaged tissue [2,4]. Bone tissue engineering relies on temporal scaffolds, which mimic the extracellular matrix (ECM) and provide a stable structure for "bone" cells' (osteoblasts) natural growing process $[2,4,5]$. In this way, the organism could regenerate itself naturally as such platforms can significantly influence the cell behavior and, as a result, the whole osseointegration of the implants in the organism [2]. In order to provide these effective qualities, the temporary $3 \mathrm{D}$ multicomponent scaffolds should mimic the interconnected porous native environment of the cells, covering their needs of nutrients, migration, adhesion, and growth. Such scaffolds should also possess the characteristics of natural bone, such as strength, stability, resistance, and surface roughness, which are crucial for improving cell adhesion, proliferation, and differentiation [2-5]. In order to achieve all these requirements, additional structuring of 3D scaffolds is needed. Femtosecond laser treatment is a non-invasive and fully biocompatible method, which perfectly fits with the idea of optimizing the bone-engineered scaffolds, as it successfully overcomes the limitations associated with traditional fabrication methods [6]. Ultra-fast laser modification allows the production of highly interconnected porous 3D platforms of one or more components, without adding any toxic components and changing biochemical properties of the matrix, while optimizing its surface topography [7-9].

Temporary platforms' composition of optimal materials is the other crucial factor for satisfying all bone cell proliferation requirements [2]. The excellent biocompatibility, biodegradability, and direct bond formation with the connective tissue [9-12] of $\beta$ tricalcium phosphate $\left(\beta-\mathrm{TCP} ; \mathrm{Ca}_{3}\left(\mathrm{PO}_{4}\right)_{2}\right)$ make it an attractive bioceramic for bone regeneration applications. Lu et al. studied the $\beta$-TCP mechanism of degradation in bone and found that, after a few weeks of implantation, a new lamellar bone was formed at the contact surface between the $\beta$-TCP implant and surrounding osteoblasts [13]. It was consequently progressively absorbed in vivo by a cell-mediated process and replaced by newly formed bone tissue $[14,15] . \beta$-TCP is used in calcium orthophosphate porous scaffolds [16-19] used as bone substitution bioceramics [20-29]. The large family of calcium orthophosphates as well as their structure, application, and characteristics are thoroughly discussed in the review of Dorozhkin [30], where they are described as very promising tools for tissue engineering applications.

The cell proliferation can be navigated in a particular direction by laser pre-treatment of the tissue-engineered matrix surface. In this way, the grooved by fs pulses surface channels the growth of future tissue in the desired direction. This was confirmed by the work of Lasgorceix et al., who demonstrated experimentally bone marrow stem cells' behavior assessment on femtosecond micropatterned $\beta$-TCP laser bioceramic surfaces [31]. Such surface functionalization is largely dependent on the surface texture and quality. Ceramic materials have a very brittle nature [30], which makes their topography modification by traditional texturing methods very difficult. Laser treatment is a progressive, non-contact technique of improving the surface characteristics of biocompatible materials, which makes it suitable for overcoming these disadvantages, and even textured patterns smaller than $100 \mu \mathrm{m}$ could be established.

The main question that arises for the fabrication of a successful implant is related to the surface properties. It is of main importance to match the ideal design for a specific target application. Various methods [32] (like photolithography, sandblasting, chemical etching and laser-based modification, and so on) are used for the creation of surface topographies on different biomaterials (metals, polymers, and ceramics) with diverse geometrical macro, micro, and nanostructures: pillars, stripes, dimples, and pits.

In the review of M. Ermis et al. [33], the substrate properties of textured polymeric and metallic biomaterials with features ranging from $100 \mathrm{~nm}$ to $100 \mu \mathrm{m}$, in accordance 
with specific cell types' feedback, are summarized. It has been demonstrated that various cell types tend to adhere to surfaces with a variation of the surface roughness from micro to nano dimensions. D. Faria et al. [34] has successfully obtained moderate roughness from 2 to $4 \mu \mathrm{m}$ by nanosecond laser texturing of TZ-3YSB-E zirconia. The strategy of texturing employs a combination of different numbers of sets, lines, and laser power. The authors demonstrated the ability of the method to produce patterns that exhibit either super hydrophobic or hydrophilic properties. They have shown the capacity of laser-based texturing for the fabrication of customized surface designs of ceramic material.

Another work from Biswas et.al. [35] explores the possibility to form surface texture via femtosecond laser on copper $(\mathrm{Cu})$ and titanium (Ti) by varying the pulse repetition rate ( 1 and $10 \mathrm{kHz}$ ). They were able to obtain structures ranging from nanoforest to fish scale.

The design of micro/nano topographical structures on Zirconia ceramics was recently reported by Sima et al. [36], for research of osteogenic response. Using laser-based femtosecond processing, the creation of isotropic- and anisotropic-geometric shapes was acquired. The microtextured zirconia ceramics provides a human mesenchymal stem cells (hMSC) enhanced environment for adhesion and orientation. Moreover, the combination of the structures of microgrooves/ridges gives additional mechanical stimuli for cellular differentiation.

Immortal cell lines, such as mouse calvaria osteoblasts (MC3T3), which were used in this study, were chosen as they represent an inexpensive, well-established model for performing preliminary experiments $[37,38]$ concerning testing the "quality" of the designed cell matrices. However, this type of cell line has some limitations, related to the in vivo simulation of the regenerative processes. For maximum imitation of the complex physiological behavior, human primary cells are the preferred choice as they generate more accurate information as far as living systems are concerned [37,39]. The adipose-derived stem cells are more appropriate cell lines in the field of tissue engineering, because of the fact that they can successfully differentiate into other tissue types like bone, cartilage, and muscle.

As a rule, primary human cells are cultured directly from their source organ tissue, and, as such, have a number of advantages over immortalized cell lines, in the context of tissue engineering, such as enhanced replication in vivo, genetic stability, defined donor characteristics, matching molecular pathways and metabolism, and so on [40]. For example, the group of Nasello et al. [41] report that micro-engineered cell scaffolds provide the exact conditions for successful human osteoblasts' primary cell line differentiation into osteocytes with a limited number of cells seeded, which, according to the authors, represents a functional strategy to create a patient-specific tissue model. Research from Panseri et.al. [42] has demonstrated that the combination of multi-scale structures with core-shell design of the scaffolds could successfully mimic the cortical bone structure. They have used human adipose-derived stem cells (hADSCs) cells as a very appropriate choice for autologous stem cells in order to boost bone regeneration. Furthermore, hADSCs can be efficiently derived from adipose tissue by minimally invasive surgery. Nevertheless, for primary experimental evaluation, the use of a standard immortal cell line is still preferred, because of the higher reproducibility of the results obtained, lower cost, and uniform cell type. Cells can be grown and expanded over longer periods of time, in standard culture conditions, with no need for special media or additives [38].

To the best of our knowledge, the influence of laser parameters, like scan speed, laser power, and repetition frequency, of the pulses has extensively examined [43-47], whereas fewer data exist concerning the influence of the number of applied laser pulses (spot scanning regime) on the processing quality of ceramic samples, which differs from the regime of linear-scanning. The development of various microstructures, in the form of bumps or pit-like, is a consequence of the selection of pulse to pulse overlap ratio [48]. The literature survey has not indicated studies related to the effect of laser-induced processing via a selection of the preferred number of applied laser pulses $(\mathrm{N})$ on ceramic biomaterial. 
In this study, laser-based methods utilizing two regimes of texturing "spot to spot" scanning and "continuous line scanning" of surface modification were applied to improve the morphological properties of the surface of $\beta$-TCP pellets for proper cell surface environment creation. The microstructured scaffolds were investigated by confocal laser scanning microscopy (CLSM), scanning electron microscopy (SEM), energy-dispersive X-ray spectroscopy (EDX), Fourier-transform infrared spectroscopy (FTIR), and X-ray diffraction (XRD) analyses. Live/dead assay analysis, Alamar Blue Assay, and actin staining of the mouse calvaria osteoblasts (MC3T3) cultured on ceramic scaffolds were performed as a part of preliminary cell seeding experiments for evaluating the effect of the patterned ceramic surface on cytotoxicity and MC3T3 orientation behavior from day 1 to 7 .

\section{Materials and Methods}

Three-dimensional Biotek $\beta$-TCP discs were purchased from Sigma-Aldrich ${ }^{\circledR}$ (Munich, Germany) and were directly laser modified, without any pre-treatment. The diameter of the pellets is approximately $9.5 \mathrm{~mm}$. The surface of the sample was divided into two zones, laser textured and non-textured, in order to distinguish the deviation of cellular orientation on the sample surface by detecting their adhesion on processed and unprocessed areas (Figure 1b).

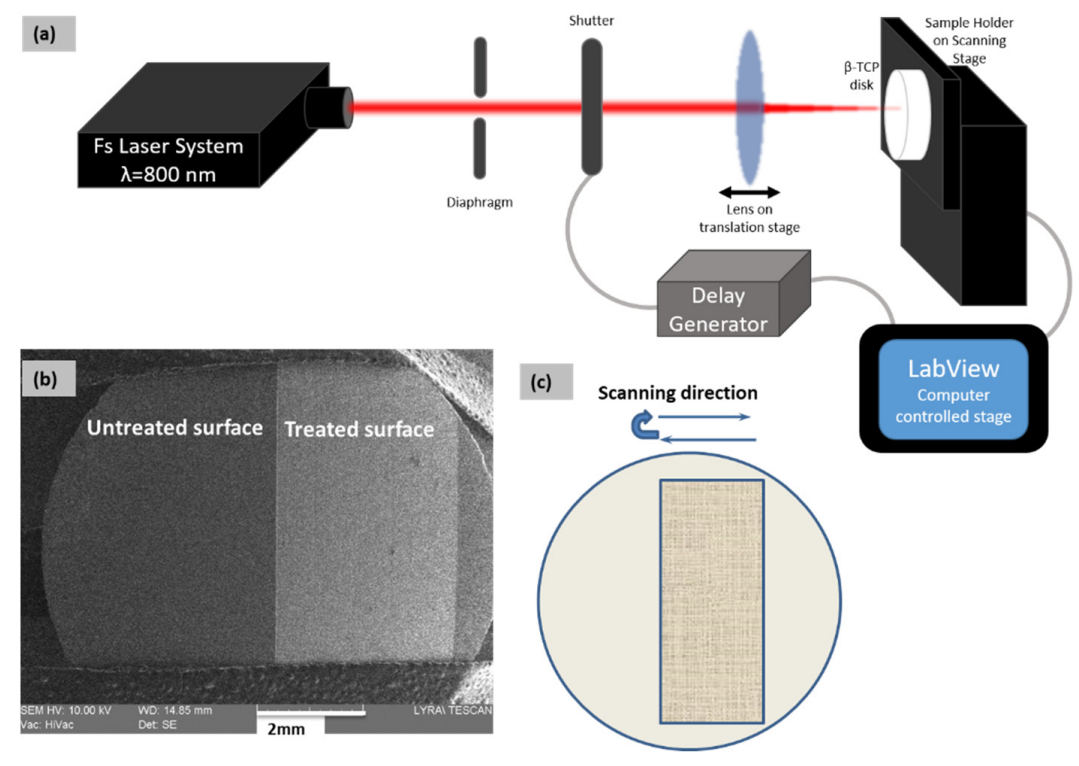

Figure 1. Experimental setup for femtosecond laser irradiation of $\beta$-tricalcium phosphate ( $\beta$-TCP) discs: (a) scheme of the setup for fs-laser microprocessing; (b) optical image of irradiation geometry on the pellet surface; (c) scanning direction of the laser beam on the surface of the $\beta$-TCP disc.

\subsection{Experimental Setup}

The experiments were performed using a regeneratively amplified Ti: sapphire modelocked Quantronix-Integra-C system (Hamden, CT, USA) delivering $130 \mathrm{fs}$ pulses at a repetition rate of $1 \mathrm{kHz}$ and central wavelength of $\lambda=800 \mathrm{~nm}$. The laser system possesses the possibility for variation of the repetition rate (from $25 \mathrm{~Hz}$ to $1 \mathrm{kHz}$ ). The sample was mounted on the XYZ translation stage perpendicularly in respect to laser beam propagation. The experiments were performed in the air. The laser beam was focused by a lens with a focal length of $f=10 \mathrm{~cm}$ to a focal spot with a diameter of approximately $\mathrm{d}=40 \mu \mathrm{m}$. The number of applied laser pulses $(\mathrm{N})$ was controlled by the computer-driven fast mechanical shutter, synchronized by precisely controlling software. The samples were processed by scanning the focused laser beam over the material surface at precisely defined separation intervals, first in the $X$ direction to produce a line pattern and afterward in the $Y$ direction. The translation was achieved between separate sets of fired laser pulses so that the laser-irradiated zone received a defined number of shots. Variation of the applied number of laser pulses (N) from 1 to 100 was performed. The influence 
on morphological change by means of laser energy and overlapping conditions between distinct pulses was studied. The impact of surface roughness and chemistry deviations on treated and untreated zones defined the most appropriate conditions for cellular proliferation. The experimental setup is presented in Figure 1.

\subsection{Methods for Qualitative Analysis of Laser-Modified Samples}

The laser-induced morphologies on the surface of the pellets were investigated by confocal laser scanning microscopy (CLSM), scanning electron microscopy (SEM), and energy-dispersive X-ray spectroscopy (EDX) analysis. The chemical composition of treated and untreated surfaces was examined by Fourier-transform infrared spectroscopy (FTIR) and X-ray diffraction (XRD) analyses. Comparison between laser-treated and untreated zones of the samples was done in all analyses.

Confocal laser scanning microscope (Leica DCM 3D) with a standard resolution of $1024 \times 768$ was used for evaluating the surface topography of the ceramic pellets, after fs-laser treatment. Three-dimensional topography images and cross sections of 3D reconstructed images of laser patterned surfaces were obtained.

For analysis of the morphology of the $\beta$-TCP pellets, SEM-TESCAN/LYRA/XMU (TESCAN ORSAY HOLDING, a.s., Brno, Czech Republic) equipped with a dual beam scanning electron/focused ion beam system was used. The system allows operation at high, medium, and low vacuum modes up to $500 \mathrm{~Pa}$. The SEM has an energy-dispersive X-ray spectroscopy (EDX) module (Quantax 200, Bruker). The scanning electron micrographs were acquired at an operational voltage of $10 \mathrm{kV}$.

All the samples were carbon sputtered with $10 \mathrm{~nm}$ thin film via a carbon sputtering system (Quorum Technologies) and images were taken at non-treated and laser treated zones of each sample. In order to analyse the elemental composition of samples' surfaces, EDX was performed before and after laser irradiation with an operational voltage of $20 \mathrm{kV}$. The samples were examined at different zones in the processed area.

IR spectra of the $\beta$-TCP discs before and after laser treatment were obtained using FTIR spectrophotometer (IR Affinity-1, Shimadzu, Kyoto, Japan) with resolution of $4 \mathrm{~cm}^{-1}$, in order to gain information about chemical bond changes and the phase transformations in the samples. The measurements were taken in transmittance mode in the range $4000-500 \mathrm{~cm}^{-1}$. XRD analysis was performed using a PANalytical-Empyrean system (Malvern Panalytical, Malvern, UK) equipped with a Cu tube and a PIXcel 3D detector. Software High Score Plus (Malvern Panalytical, Malvern, UK) was used to analyse the obtained X-ray diffraction data of the $\beta$-TCP discs' surface after laser treatment. The experimental conditions were as follows: $40 \mathrm{kV}, 40 \mathrm{~mA}$, exposition $100 \mathrm{~s}$, and step 0.03 degree.

\subsection{MC3T3 Cell Seeding, Culture, and Staining on Laser-Textured Samples}

MC3T3 is an immortalized cell line obtained from mouse calvaria tissue. It is used to assess the possible cytotoxic effect of surfaces and orientation ability on the patterned ceramic surface, as they represent one of the most reliable osteoblast-like cell lines. It possesses a high level of differentiation degree and the possibility to influence the mineralization process. The osseointegration process comprises a number of cell interactions: adhesion, proliferation, and differentiation followed by matrix mineralization. Thus, by cultivating these types of cell lines on the processed ceramic samples, an in vitro model is established for monitoring cell adhesion and spreading.

The samples were sterilized by immersing them in a 70\% ethanol solution for 8 days. Mouse calvaria osteoblasts (MC3T3) (ATCC) were cultured in Dulbecco's Modified Eagle Medium (DMEM) Glutamax (GibcoTM; Invitrogen, Thermo Fischer Scientific, Waltham, MA, USA) supplemented with $10 \%$ fetal bovine serum and $1 \%$ penicillin/streptomycin in a humidified atmosphere at $37{ }^{\circ} \mathrm{C}$ and $5 \% \mathrm{CO}_{2}$. Before cell seeding, the sterilized samples were preincubated in complete cell culture medium for 8 days at $37^{\circ} \mathrm{C}$. Subsequently, MC3T3 cells were seeded on the ceramic laser patterned samples or tissue culture plastic (positive control) in a 48 -well plate. A cell suspension of 100,000 cells in $30 \mu \mathrm{L}$ culture 
medium was pipetted onto the samples. After $4 \mathrm{~h}$, an additional culture medium ( $1 \mathrm{~mL})$ was added. Culture medium was refreshed every second day. Tissue culture plastic without seeded cells was used as a negative control.

Cell proliferation was evaluated after 1, 4, and 6 days by performing an Alamar Blue Assay. After placing the samples in another well, rinsing was performed using $1 \mathrm{~mL}$ phosphate buffered saline (PBS). An Alamar Blue stock solution was prepared $(440 \mu \mathrm{M})$ consisting of resazurin sodium salt (Sigma-Aldrich; 199303) and HBSS (free from serum and phenol-red) (Invitrogen; 14025-050). After removing the PBS, $500 \mu \mathrm{L}$ of an Alamar Blue working solution (1:10 diluted stock solution) was added to each sample. Subsequently, the samples were incubated for $2 \mathrm{~h}$ at $37^{\circ} \mathrm{C}$ in the dark. Post-incubation, $200 \mu \mathrm{L}$ of the Alamar Blue working solution of each sample was transferred to a 96 microtiter well plate in duplicate. Fluorescence was measured at $560 \mathrm{~nm} / 590 \mathrm{~nm}$ using the GloMax ${ }^{\circledR}$ Discover Microplate Reader (Promega, Madison, WI, USA).

Live/dead staining with calcein-AM/propidium iodide was performed on day 7 of culture to evaluate cell viability and cell morphology. After rinsing the samples, the supernatant was replaced with $500 \mu \mathrm{L}$ PBS supplemented with $1 \mu \mathrm{L}(1 \mathrm{mg} / \mathrm{mL})$ calcein-AM (Anaspec, Fremont, CA, USA) and $1 \mu \mathrm{L}(1 \mathrm{mg} / \mathrm{mL})$ propidium iodide (Sigma-Aldrich; P4170). After 10 min incubation in the dark at room temperature, the samples were evaluated with the Zeiss Zen software by an AxioCam (ICc 1) camera mounted on a fluorescence microscope (AxioVert A1, Zeiss, Jena, Germany).

\subsection{Confocal Microscopy of Actin Staining}

Cells cultured on patterned and control substrates were stained after $48 \mathrm{~h}$. They were fixed in formalin for $10 \mathrm{~min}$, and subsequently cleaned with PBS. The cells were then permeabilized with $30 \mu \mathrm{L}$ of Triton, and washed again with PBS. Afterwards, a specific blocking of $2 \%$ bovine serum albumin (BSA) for $10 \mathrm{~min}$ was added. The staining was prepared with antibody dilution of 1:40 and left for incubation for $1 \mathrm{~h}$. Actin filaments were stained with Rhodamine Phalloidin conjugated 488. Fluorescent images of cell cytoskeleton were obtained with a Leica TCS SP8 confocal microscope (Leica Microsystems). Samples were excited at $488 \mathrm{~nm}$, and the emissions were recorded in the detection range of 500-550 $\mathrm{nm}$.

\section{Results}

\subsection{SEM, EDX, and Confocal Analysis of $\beta$-TCP Discs}

Figure 2 shows SEM images before and after laser treatment with $N=1,10$, and 100 pulses and $\mathrm{F}=0.8 \mathrm{~J} / \mathrm{cm}^{2}$. The selection of the representative morphological pictures acquired for laser irradiation with $\mathrm{N}=1,10$, and 100 was done on the basis of monitoring distinct transitions in the process of laser ablation, which occurred after a certain change (an increase of $\mathrm{N}$ ) of applied laser parameters-Table 1. This permits us to define concrete parametric conditions, from which the morphological changes on the surface and in the bulk of the material are triggered, as well as to separate material changes related to the frame interval of $\mathrm{N}=1, \mathrm{~N}=10$, and $\mathrm{N}=100$.

A clear difference in the morphological patterns of the $\beta$-TCP surfaces was noted after laser modification - the visible granular surface of the untreated $\beta$-TCP pellets (Control $\beta$-TCP- a group I) is replaced by gentle surface patterning, in the case of $\mathrm{N}=1(\mathrm{~N}=1$, $\mathrm{F}=0.8 \mathrm{~J} / \mathrm{cm}^{2}$ group II), with the initiation of the first signs of material ejection. No grooves and cracks are observed for this type of processing condition. As we increase further the number of laser pulses to 10, grooves are formed on the surface with clear edges and without the onset of melted zones $\left(\mathrm{N}=10, \mathrm{~F}=0.8 \mathrm{~J} / \mathrm{cm}^{2}\right.$ group III). In the case of $\mathrm{N}$ $=100$ (group IV), severe laser modification of the sample is achieved and the ablation proceeds with the ejection of the ceramic material at the edges of the processed area. The formation of cracks around the crater boundary is monitored, which leads to disturbance of the $\beta$-TCP material integrity (Figure 2). Analogical laser patterning is established when $\mathrm{F}=1.25 \mathrm{~J} / \mathrm{cm}^{2}$ and $\mathrm{N}=5 \div 100$ are applied (Figure 3). By increasing the number of pulses, the creation of grooves with subsequent formation of ripples and cracks is observed. 
Adjusting the number of pulses and the applied fluence contributes to the optimization of the $\beta$-TCP surface modification. The laser-induced micro-features could improve the surface roughness of the $\beta$-TCP pellets and, subsequently, affect cellular behavior such as adhesion, morphology, migration direction, and differentiation.

Group I

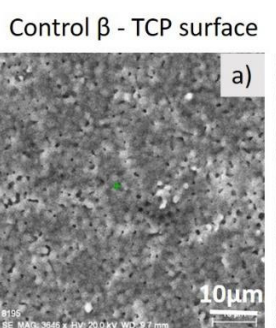

Group II

$\mathrm{N}=1, \mathrm{~F}=0.8 \mathrm{~J} / \mathrm{cm}^{2}$

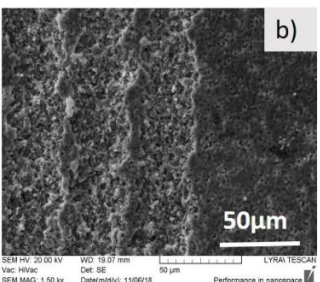

$50 \mu \mathrm{m}$

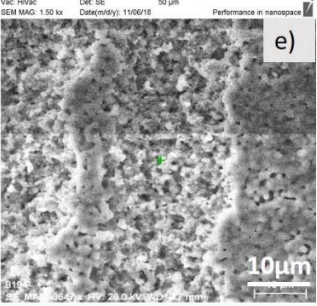

Group III

$\mathrm{N}=10, \mathrm{~F}=0.8 \mathrm{~J} / \mathrm{cm}^{2}$
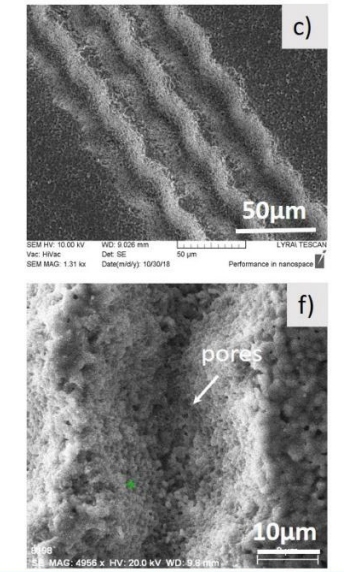

\begin{tabular}{|l|l|l|l|l|}
\hline Elements & Control $\beta$ - TCP surface & $\mathrm{N}=1, \mathrm{~F}=0.8 \mathrm{~J} / \mathrm{cm}^{2}$ & $\mathrm{~N}=10, \mathrm{~F}=0.8 \mathrm{~J} / \mathrm{cm}^{2}$ & $\mathrm{~N}=\mathbf{1 0 0}, \mathrm{F}=0.8 \mathrm{~J} / \mathrm{cm}^{2}$ \\
\hline $\mathrm{O}$ & 38.46 & 58.02 & 67.18 & 48.78 \\
\hline $\mathrm{Ca}$ & 39.91 & 29.17 & 27.67 & 34.03 \\
\hline $\mathrm{P}$ & 17.27 & 15.72 & 15.30 & 13.55 \\
\hline $\mathrm{C}$ & 4.45 & 3.29 & 2.94 & 1.93 \\
\hline
\end{tabular}

Figure 2. Scanning electron microscopy (SEM) images (a-g) and table of energy-dispersive X-ray spectroscopy (EDX) results, showing element concentration [wt.\%] of $\beta$-tricalcium phosphate $(\beta-\mathrm{TCP})$ pellets, as follows (from left to right): untreated surface (control) and treated with $\mathrm{N}=1,10$, and 100 pulses; $F=0.8 \mathrm{~J} / \mathrm{cm}^{2} ; \lambda=800 \mathrm{~nm} ; \tau=130 \mathrm{fs}$.

Table 1. Correlation between used processing parameters and dimensions of the obtained surface patterns in the spot by spot scanning regime.

\begin{tabular}{|c|c|c|c|c|}
\hline Number of Pulses (N) & $\begin{array}{l}\text { Pattern Width } \\
\quad\left(d_{x}\right)\end{array}$ & $\begin{array}{l}\text { Pattern Depth } \\
\left(d_{y}\right)\end{array}$ & $\begin{array}{l}\text { Mean Roughness } \\
\left(S_{a}\right)\end{array}$ & Result from Processing \\
\hline $\mathrm{N}=1$ & $4.5 \mu \mathrm{m}$ & $4 \mu \mathrm{m}$ & $1.31 \mu \mathrm{m}$ & $\begin{array}{l}\text { Modified surface without onset of cracks, gentle } \\
\text { ablation. }\end{array}$ \\
\hline $\mathrm{N}=10$ & $21.5 \mu \mathrm{m}$ & $19.5 \mu \mathrm{m}$ & $1.56 \mu \mathrm{m}$ & $\begin{array}{c}\text { Observation of deeper grooves, formation of cavities } \\
\text { without the onset of melting. }\end{array}$ \\
\hline $\mathrm{N}=100$ & $30 \mu \mathrm{m}$ & $27.5 \mu \mathrm{m}$ & $2.06 \mu \mathrm{m}$ & $\begin{array}{c}\text { Deep grooves with observation of material ejection on } \\
\text { the sides of the processed zone. }\end{array}$ \\
\hline
\end{tabular}

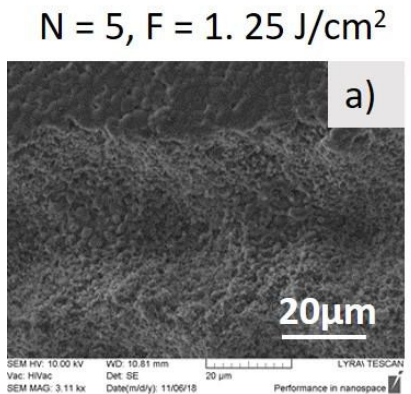

$$
\mathrm{N}=5, \mathrm{~F}=1.25 \mathrm{~J} / \mathrm{cm}^{2}
$$

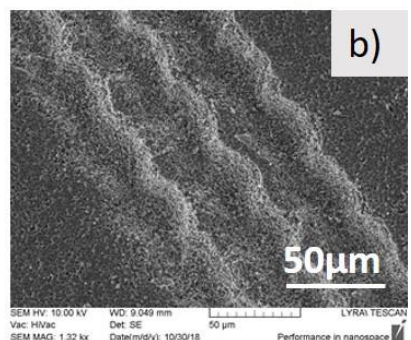

$\mathrm{N}=100, \mathrm{~F}=1.25 \mathrm{~J} / \mathrm{cm}^{2}$

$\mathrm{N}=100, \mathrm{~F}=1.25 \mathrm{~J} / \mathrm{cm}^{2}$
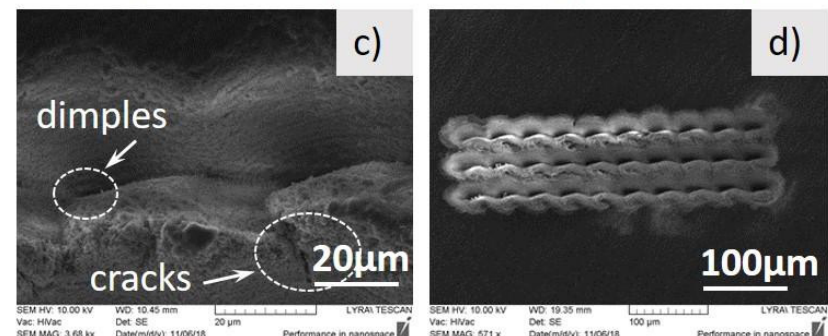

Figure 3. SEM images of surface-modified $\beta$-TCP pellets in the form of microchannels formed after laser irradiation in spot-to-spot scanning regime with fs-laser pulses for the following: $\mathrm{N}=5(\mathbf{a}, \mathbf{b})$ and $100(\mathbf{c}, \mathbf{d}) ; \mathrm{F}=1.25 \mathrm{~J} / \mathrm{cm}^{2}, \lambda=800 \mathrm{~nm}, \tau=130 \mathrm{fs}$. 
The EDX spectra results presented in a table, showing the element concentration [wt.\%] of $\beta$-TCP discs before and after laser treatment, are shown in Figure 2. The control $\beta$-TCP samples revealed the presence of oxygen $(\mathrm{O})$, calcium $(\mathrm{Ca})$, phosphorus $(\mathrm{P})$, and carbon $(\mathrm{C})$, which are commonly present chemical elements in the $\beta$-tricalcium phosphate $\left(\mathrm{Ca}_{3}\left(\mathrm{PO}_{4}\right)_{2}\right)$. The data showed a reduced amount of $\mathrm{Ca}, \mathrm{P}$, and $\mathrm{C}$ elements and an elevated level of oxygen $\mathrm{O}$ by increasing the number of applied laser pulses (Figure 2 group I-IV). The only exception is at $\mathrm{N}=100$ (Figure 2 group IV), when $\mathrm{O}$ element concentration [wt.\%] decreased and the Ca amount increased in relation to the control (untreated) $\beta$-TCP sample. This result could be attributed to the fact that, by applying a higher number of laser pulses, a subsequent increase of Ca-P bonds' fragmentation is observed owing to increased material ejection, triggered from the high-intensity femtosecond laser-matter interaction, thus confirming once again that optimizing laser parameters is crucial for such topography modifications.

For both laser fluences $\left(F=0.8 \mathrm{~J} / \mathrm{cm}^{2}\right.$ and $\left.\mathrm{F}=1.25 \mathrm{~J} / \mathrm{cm}^{2}\right)$, the formation of recasts along the boundaries of the processed channel for $\mathrm{N}=100$ is monitored. Moreover, the bottoms of the microchannels are characterized by the formation of dimple-like structures. The effect of the influence of a number of applied laser pulses on the width of produced microchannels in spot by spot regime demonstrated in Figure 3 is shown in the plot below (Figure 4).

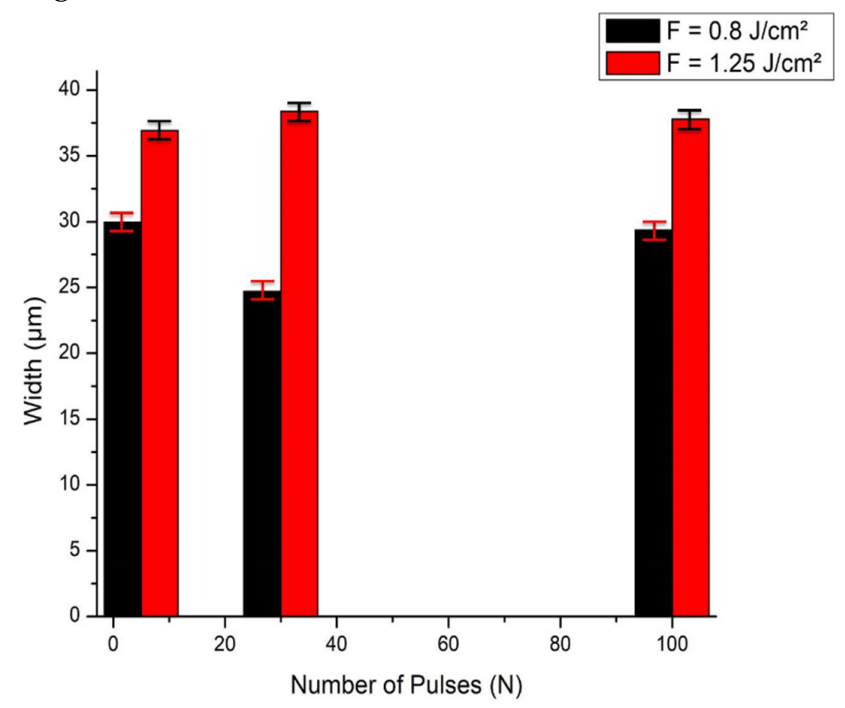

Figure 4. Dependence of micro-channel width $( \pm 2.2 \mu \mathrm{m})$ versus pulse counts in spot by spot regime, obtained at two diverse laser fluences: $\mathrm{F}=0.8 \mathrm{~J} / \mathrm{cm}^{2}$ and $\mathrm{F}=1.25 \mathrm{~J} / \mathrm{cm}^{2}$ and $\mathrm{N}=5,30$, and 100; $\lambda=800 \mathrm{~nm} ; \tau=130 \mathrm{fs}$.

The increasing number of applied laser pulses influences the dimensions of microchannels in the low power regime more notably. It is observed that the boundary morphologies of the micro-channels are strongly affected by the influence of the increasing number of pulses, resulting in a micro-channel width increment. This increment shows a stable tendency for $\mathrm{F}=1.25 \mathrm{~J} / \mathrm{cm}^{2}$ and for $\mathrm{N}, 5,30$, and 100 . The results demonstrate that the increase of the micro channel width can be a contribution from two parameters: laser energy and the number of applied laser pulses, which will be evaluated in the next studies. Thus, it will be possible to optimize the laser modification process via the interplay between pulse counts and laser fluence. This can lead to the precise tuning of material modification with high processing efficiency via a selection of the number of pulses applied.

In order to obtain the ideal surface properties of the created grooves, tests were carried out to study the effect of scan speed velocity in continuous mode on grooves' morphology. Figure 5 shows the typical SEM morphologies of micro-grooves processed with constant laser fluence $F=1.03 \mathrm{~J} / \mathrm{cm}^{2}$ and $F=0.61 \mathrm{~J} / \mathrm{cm}^{2}$ for two diverse scan velocities $\mathrm{V}=1.7 \mathrm{~mm} / \mathrm{s}$ and $\mathrm{V}=3.8 \mathrm{~mm} / \mathrm{s}$. 

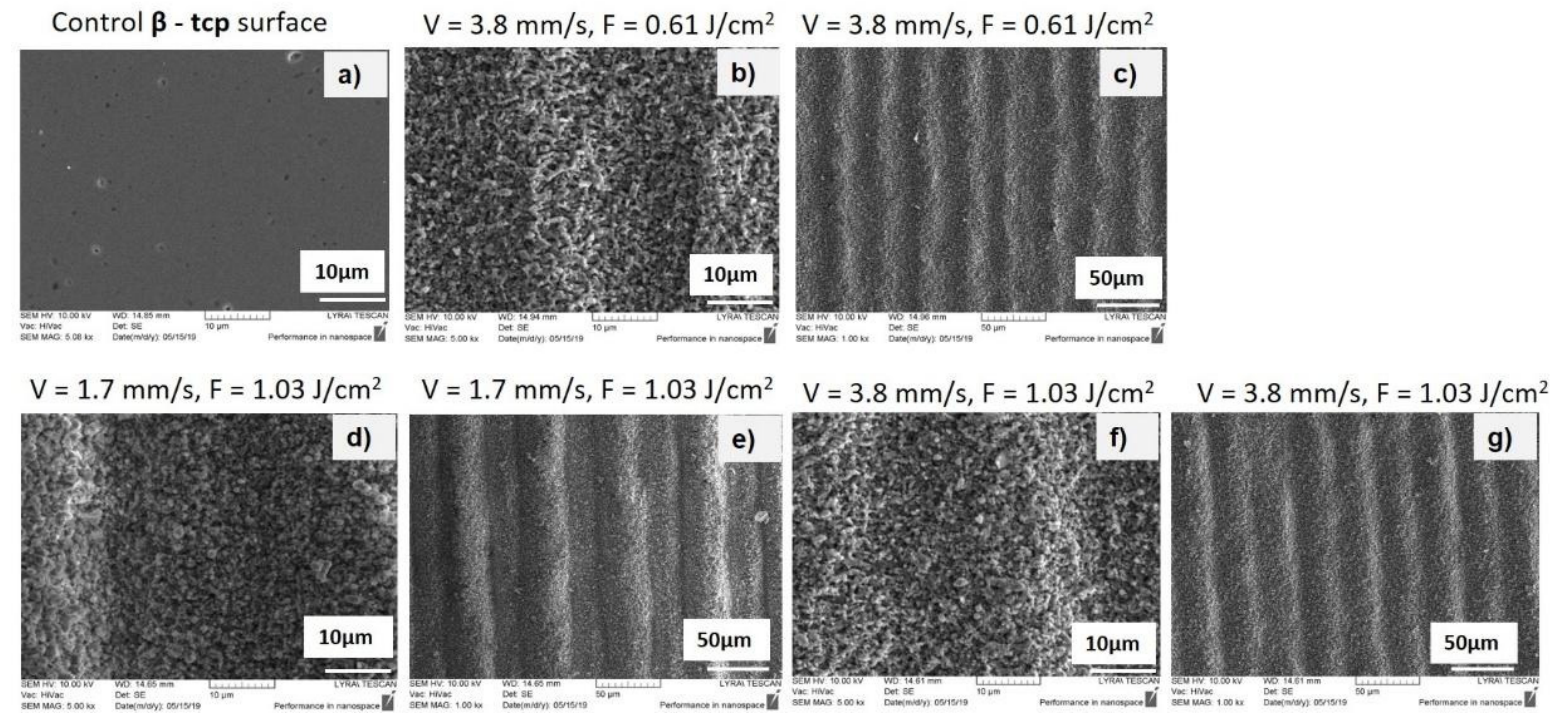

Figure 5. SEM images of surface-modified $\beta$-TCP pellets in the form of microchannels formed after laser irradiation in continuous line scan regime with fs-laser pulses for the following: control surface (a) and laser modified at $\mathrm{F}=0.61 \mathrm{~J} / \mathrm{cm}^{2}$ and $\mathrm{V}=3.8 \mathrm{~mm} / \mathrm{s}(\mathbf{b}, \mathbf{c})$ and $\mathrm{F}=1.03 \mathrm{~J} / \mathrm{cm}^{2}, \mathrm{~V}=1.7(\mathbf{d}, \mathbf{e})$, and $\mathrm{F}=1.03 \mathrm{~J} / \mathrm{cm}^{2}, \mathrm{v}=3.8 \mathrm{~mm} / \mathrm{s} ; \lambda=800 \mathrm{~nm} ; \tau=130 \mathrm{fs}(\mathbf{f}, \mathbf{g})$.

From Figure 5, the formation of clear grooves' morphology for all of the applied settings is illustrated, the edges and bottoms of the valleys are smooth, without signs of molten material. For laser fluence, $\mathrm{F}=1.03 \mathrm{~J} / \mathrm{cm}^{2}$ and $\mathrm{V}=1.7 \mathrm{~mm} / \mathrm{s}$, more pronounced micro-grooves with the formation of wavy-like topography are observed. When the laser scanning speed is lower $(\mathrm{V}=1.7 \mathrm{~mm} / \mathrm{s})$, a higher overlap ratio of the pulses leads to excessive energy accumulation and increasing ablation of the material, with the formation of deeper microchannels.

We performed confocal microscopy analysis on laser-induced modification $\beta$-TCP samples in the continuous laser scanning regime-Figure 6.

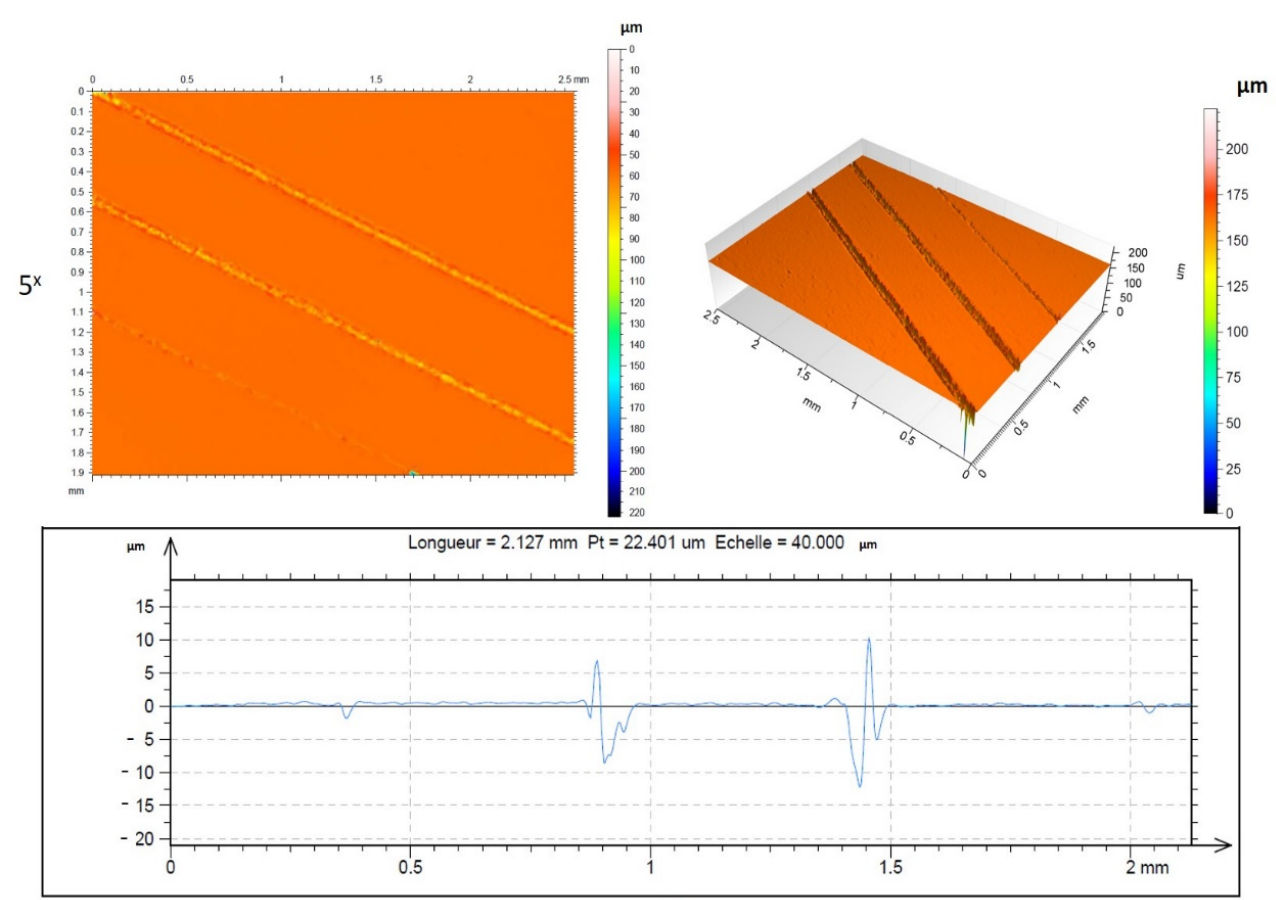

(a)

Figure 6. Cont. 

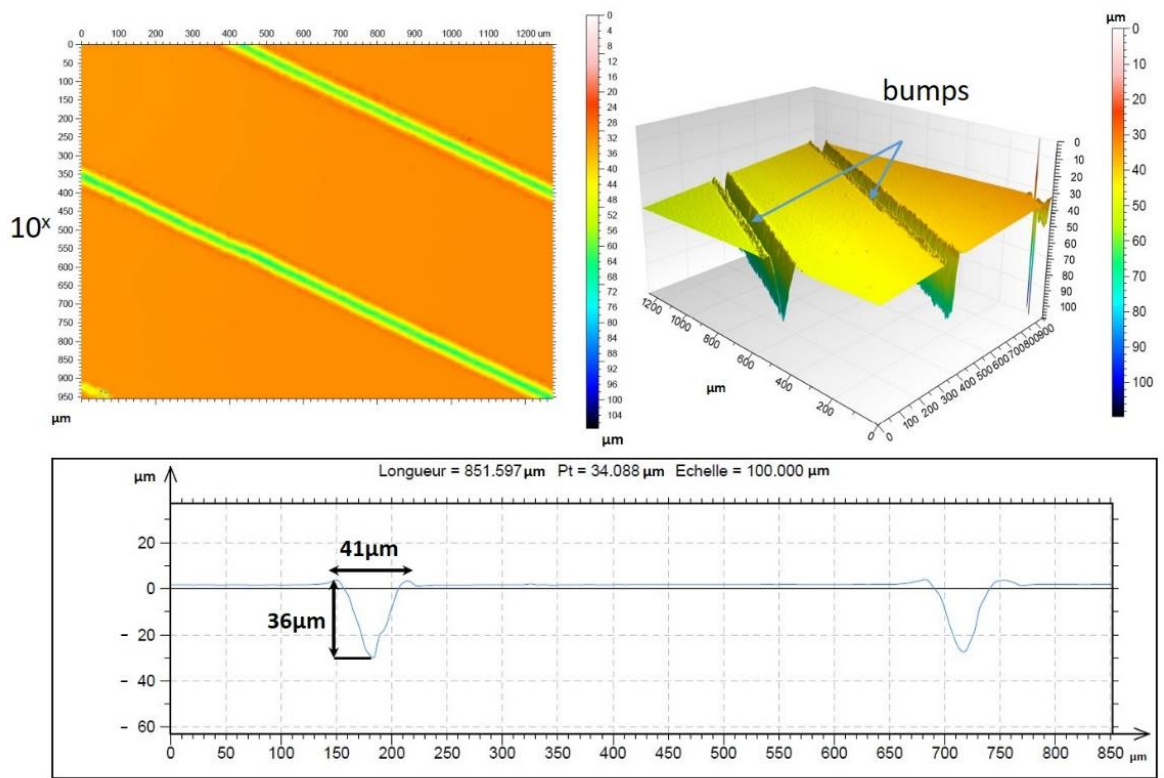

(b)

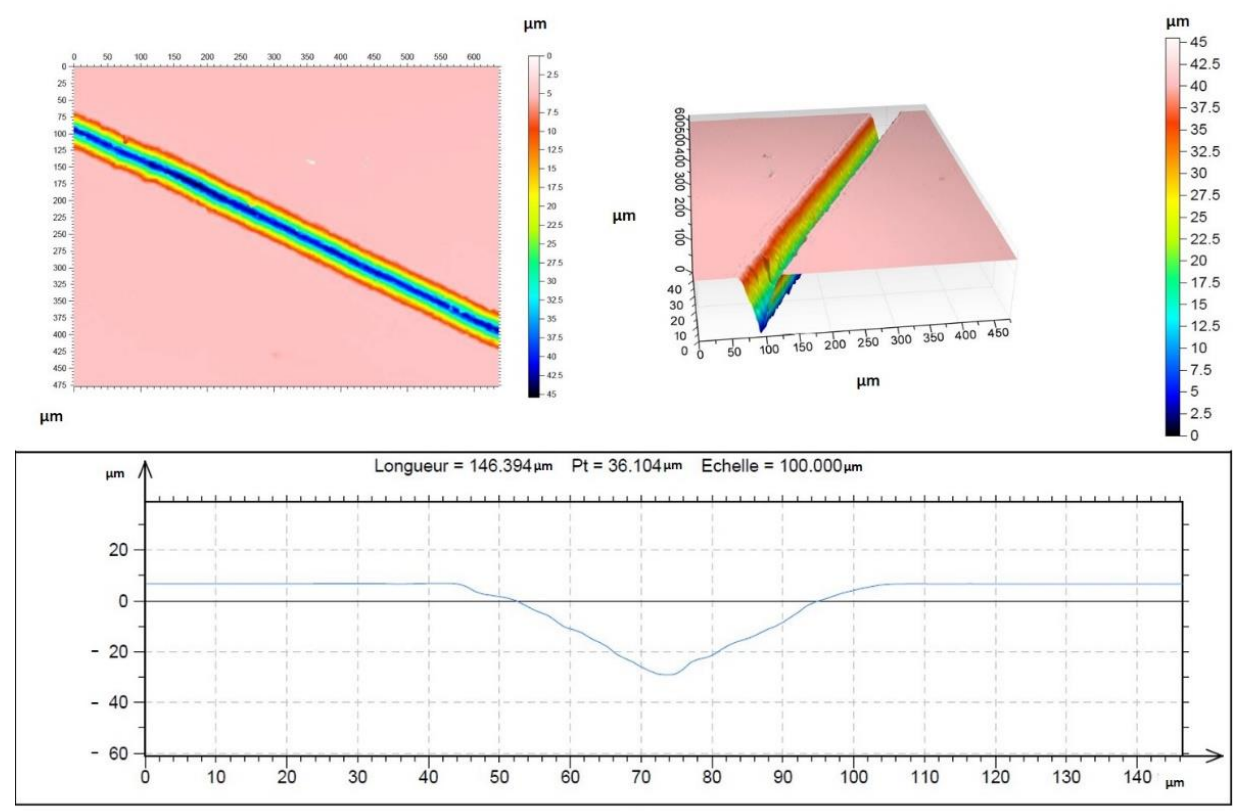

(c)

Figure 6. Confocal microscope (CLSM) images of femtosecond laser created microchannels on the surface of $\beta$-TCP pellets in continuous line scanning mode with $\mathrm{F}=1.03 \mathrm{~J} / \mathrm{cm}^{2}$ and scanning speed $\mathrm{V}=1.7 \mathrm{~mm} / \mathrm{s}$ at three different magnifications: $(\mathbf{a}) 5 \times$, (b) 10×, and (c) 20×, each showing the topography image, 3D reconstructed image, and cross section of the irradiated zone.

The groove morphology has a well-defined $\mathrm{V}$ shape in-depth, without evidence of mechanical distortion of the material for the highest value of laser fluence $F=1.03 \mathrm{~J} / \mathrm{cm}^{2}$ and modest velocity. The obtained width and depth of the $V$ shape are $d_{x}=41 \mu \mathrm{m}$ and $\mathrm{d}_{\mathrm{y}}=36 \mu \mathrm{m}$, respectively.

An overall observation is related to the development of clear cuts. Side effects are monitored around the edges of the created grooves, expressed in elevations of the material around the groove's boundaries. This could be attributed to melting, which can occur as a result of resolidification of the material in the line-scan mode of texturing. 


\subsection{FTIR Analysis of $\beta$-TCP Discs}

Figure 7 represents the FTIR spectrum of control/ $\beta$-TCP surfaces treated by laser irradiation at $\mathrm{F}=1.66$ and $2.07 \mathrm{~J} / \mathrm{cm}^{2}, \mathrm{~N}=5$ and 10 .

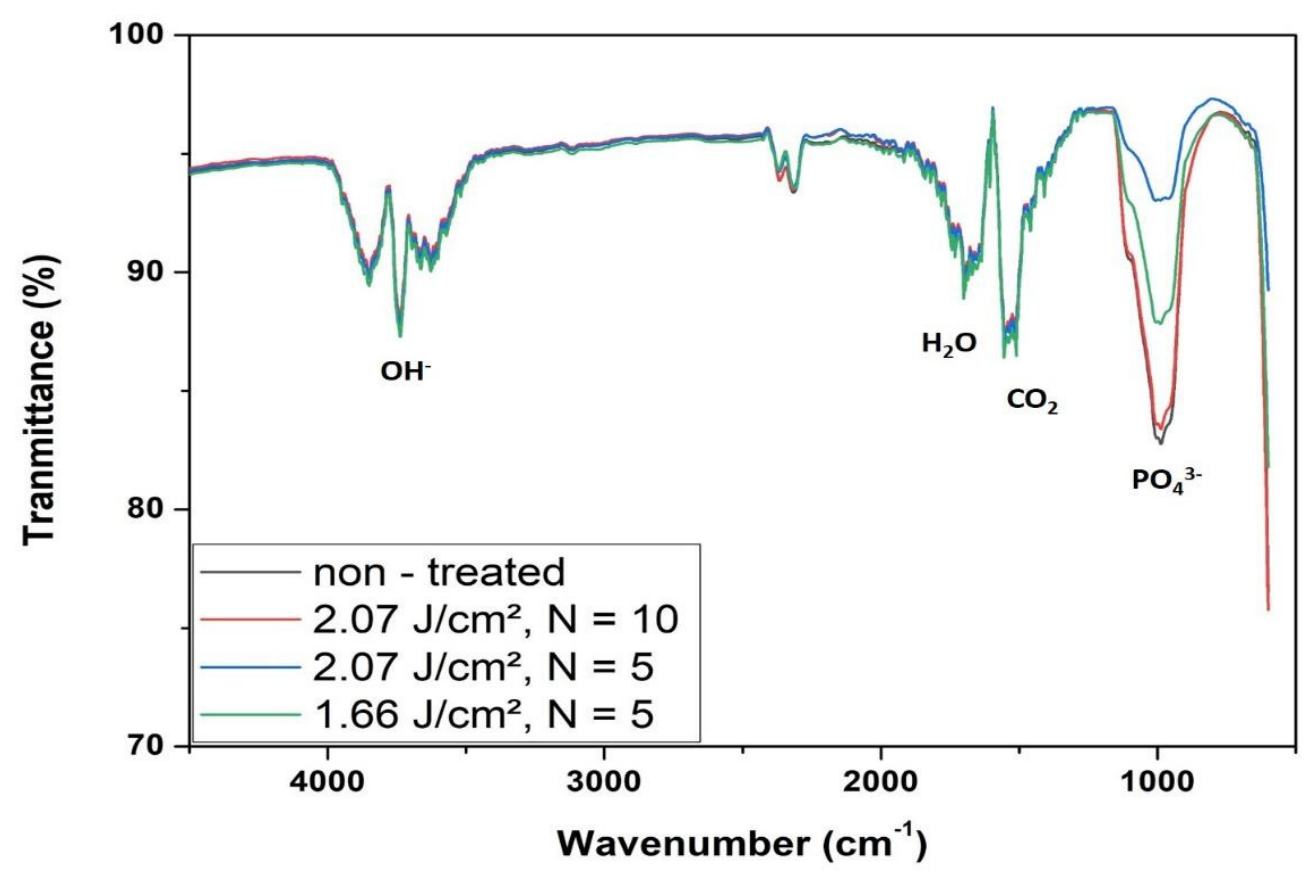

Figure 7. FTIR spectrum of $\beta$-TCP surfaces untreated/treated by laser irradiation at $\mathrm{F}=1.66$ and $2.07 \mathrm{~J} / \mathrm{cm}^{2}, \mathrm{~N}=5$ and 10 .

Some differences in the spectra measured of the non-treated and laser-processed surfaces of the $\beta$-TCP substrates are observed. The FTIR and XRD spectra were acquired at a higher fluence regime in order to test the threshold for the occurrence of drastic chemical changes. The results presented in the figure illustrate the equal number and position of various transmittance peaks, but with a remarkable difference in their intensity. All the bands in the FTIR spectra at Figure 7 correspond to stretching (between 900 and $1130 \mathrm{~cm}^{-1}$ ) and bending (between 550 and $600 \mathrm{~cm}^{-1}$ ) vibrations of $\mathrm{PO}_{4}{ }^{-3}$ groups. The peaks at 3460 and $1650 \mathrm{~cm}^{-1}$ can be assigned to adsorbed $\mathrm{H}_{2} \mathrm{O}$ and $\mathrm{CO}_{2}\left(\right.$ at $\left.1637 \mathrm{~cm}^{-1}\right)$ [43]. The shapes of the spectra from all laser processed $\beta$-TCP samples look similar, but they are much more pronounced in the case of the laser-irradiated samples examined in comparison with the control. The intensity of the peaks attributed to $\mathrm{H}_{2} \mathrm{O}$ and $\mathrm{CO}_{2}$ is the highest when applying $\mathrm{N}=5$ and $\mathrm{F}=1.66 \mathrm{~J} / \mathrm{cm}^{2}$, while the peaks of the $\mathrm{PO}_{4}{ }^{-3}$ group display with the highest intensity when an increased number of pulses $(\mathrm{N}=10)$ and fluence $\left(\mathrm{F}=2.07 \mathrm{~J} / \mathrm{cm}^{2}\right)$ is applied. This could be attributed to the higher energy input of the fs pulses, causing stronger vibrations of the $\mathrm{PO}_{4}{ }^{-3}$ group, which in turn results in higher peak intensity. This result strongly correlates with the XRD results presented afterward, and could be connected to the $\beta-\alpha$ transition. The characteristic lines, usually arising due to a possible defect of calcium, at 723,1185 , and $1210 \mathrm{~cm}^{-1}$, were not observed. According to Boilet et al. [49], this shows that the $\beta$-TCP pellets are free of the unwanted calcium pyrophosphate $\left(\mathrm{Ca}_{2} \mathrm{P}_{2} \mathrm{O}_{7}\right)$. The absorption bands of $\mathrm{PO}_{4}{ }^{-3}$ functional groups confirm the presence of the TCP phase in all examined samples.

\subsection{XRD Analysis}

Tricalcium phosphate (TCP) has four polymorphic forms [50]: $\alpha, \beta, \alpha^{\prime}$, and $\gamma$ (the last two are not of interest, because of their instability). As mentioned earlier in the text, $\beta$-TCP is famous for its remarkable osteoconductivity and biocompatibility. In contrast, the degradation rate of $\alpha$-TCP is much higher in relation to $\beta$-TCP [51]. As a result, the 
higher local $\mathrm{Ca}^{2+}$ and $\mathrm{PO}_{4}{ }^{3-}$ concentration in body fluids, caused by the rapid dissolution of $\alpha$-TCP, could obstruct the bone formation [52]. To examine which TCP ( $\alpha$ or $\beta$ form) was the primary calcium phosphate phase in our probes and to distinguish the differences between $\alpha$-TCP and $\beta$-TCP crystals, XRD analysis was performed. Figure 8 presents the $X$-ray diffraction patterns of control/ $\beta$-TCP surfaces, analyzed in the $2 \theta$ angle and treated by laser irradiation at $\mathrm{F}=1.66$ and $2.07 \mathrm{~J} / \mathrm{cm}^{2}, \mathrm{~N}=5$ and 10 . As can be seen from the figure, peaks of both $\alpha$-TCP and $\beta$-TCP are observed. The presence of $\alpha$-TCP was confirmed by the main reflection at $2 \theta$ of $12.2^{\circ}, 22.3^{\circ}, 24.3^{\circ}$, and $30.9^{\circ}$, while the presence of $\beta$-TCP revealed the main reflection at $27.8^{\circ}, 25.9^{\circ}, 31.2^{\circ}$, and $33.1^{\circ}$ [53]. However, there exists a significant difference in the peak intensity of XRD patterns for $\alpha$-TCP and $\beta$-TCP, after fs-laser modification. At $\mathrm{F}=2.07 \mathrm{~J} / \mathrm{cm}^{2}$ and $\mathrm{N}=10$ pulses, the detected majority of phases obtained from the inside part of the processed samples grooves is transformed from $\beta$-TCP to $\alpha$-TCP. Decreasing the values of laser parameters to $F=1.66 \mathrm{~J} / \mathrm{cm}^{2}$ and $\mathrm{N}=5$ or 10 leads to a reduction of the transformation of $\beta$-TCP into $\alpha$-TCP phase, while still allowing gentle surface processing. These results are crucial for the optimization of the laser parameters in order to obtain textured $\beta$-TCP substrates without the presence of unwanted $\alpha$-TCP secondary phases. It can be concluded that both XRD and FTIR analyses contributed to optimizing the fs-laser modification parameters for further biological evaluation with MC3T3 osteoblasts cell line on $\beta$-TCP grooved samples.

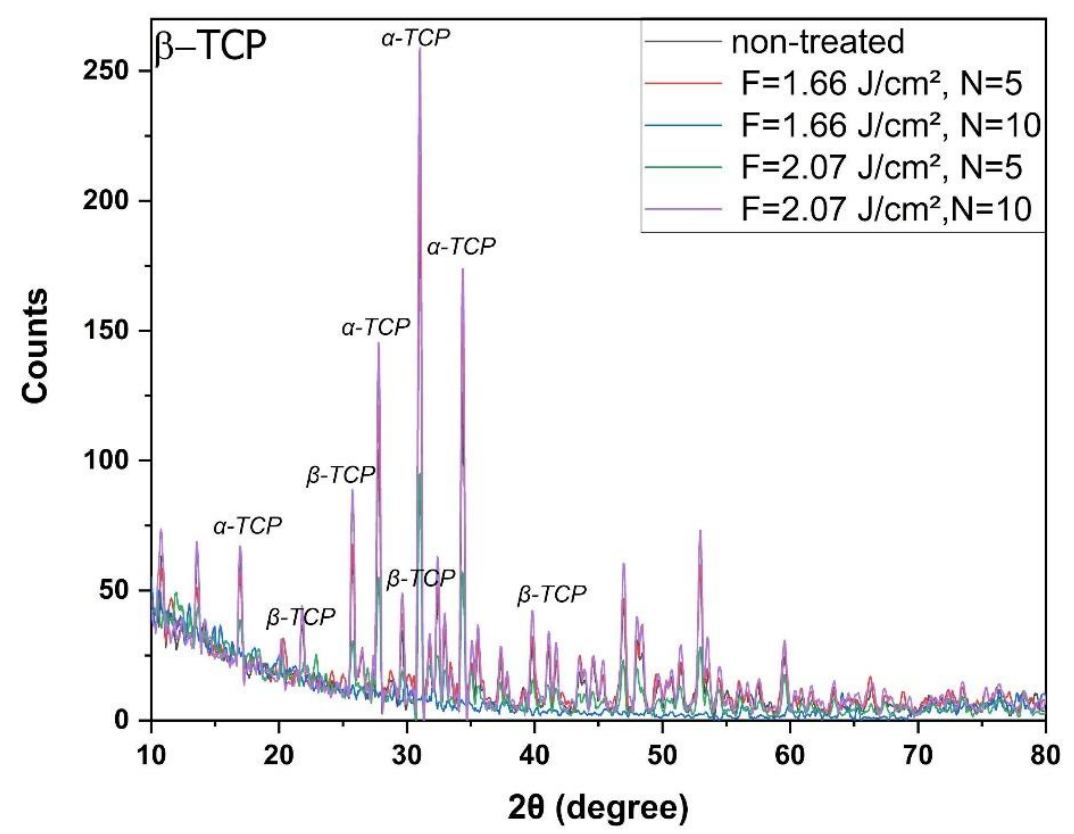

Figure 8. X-ray diffraction patterns of control $/ \beta-\mathrm{TCP}$ surfaces treated by laser irradiation at $\mathrm{F}=1.66$ and $2.07 \mathrm{~J} / \mathrm{cm}^{2}, \mathrm{~N}=5$ and 10 .

\subsection{Cell Culture and Proliferation on Laser Patterned $\beta$-TCP and ATZ (Alumina Toughened Zirconia) Ceramic Scaffolds}

In order to determine the cellular behavior of diverse surface textures, the sample area was divided into two zones, patterned and non-modified areas. The spacing between separate stripes was controlled by the scanning velocity as well as in the second mode of operation by a selection of the distance separation between the individual spots, created by the laser-Table 2. 
Table 2. Parameters employed for texturing in two different regimes of femtosecond laser patterning.

\begin{tabular}{ccccc}
\hline Sample № & $\boldsymbol{v}(\mathbf{K H z})$ & $\begin{array}{c}\text { Type I Regime: } \\
\text { Continuous Scanning. } \\
\text { (Scan Speed }(\mathbf{m m} / \mathbf{s}))\end{array}$ & $\begin{array}{c}\text { Type II Regime: } \\
\text { Spot by Spot Scanning } \\
(\mathbf{N u m b e r} \text { of Laser Pulses }(\mathbf{N}))\end{array}$ & $\mathbf{F}\left(\mathbf{J} / \mathbf{c m}^{2}\right)$ \\
\hline 1. $\beta$-TCP S5 & 500 & $1.7 ; 3.8$ & - & 1.03 \\
2. $\beta$-TCP S6 & 500 & $1.7 ; 3.8$ & - & 0.61 \\
3. $\beta$-TCP S10 & 25 & - & $1,2,5,10$ & 1.03 \\
4. $\beta$-TCP S11 & 25 & - & $1,2,5,10$ & 0.61 \\
5. $\beta$-TCP S12 & 25 & - & - & 1.86 \\
6. ATZ 5 & 500 & $1.7 ; 3.8$ & - & 1.86 \\
7. ATZ 6 & 500 & $0.5 ; 0.8 ; 16$ & -10 & 1.86 \\
\hline
\end{tabular}

The attachment of cells onto a ceramic material is an important factor in different cellular processes, such as cell proliferation, and is thus important to consider while choosing a suitable biomaterial. Laser-patterned surfaces forming grooves are known to affect the morphology of the cell by elongation.

The results from the live/dead staining on day 7 showed that all patterned substrates indicate affinity to orientate MC3T3 cells over the 7-day culture period. Figures 9 and 10 show representative images obtained by fluorescence microscopy, after 7 days of the culture of MC3T3 cell lines on diverse designs of topographically textured surfaces. To have a comparison with diverse types of ceramic scaffolds, fluorescent measurements were also done on laser-treated ATZ samples (Figure 10). Previously, a complete report on ATZ patterning was done and demonstrated selectively structured morphologies with outstanding topographical properties [48]. On all surfaces, viable cells were detected (green) (Figures 9 and 10). When compared with the positive control (Figure 10), where cells were seeded on the tissue culture polystyrene, fewer cells were present on the samples. This was also confirmed by the Alamar Blue assay (Figure 11), where the fluorescent signal for the positive control was much higher in comparison with the signal from the samples.

After a culture period of 7 days, the cells start to elongate, following the pattern on the scaffold (white lines) (Figures 9 and 10). Detailed images without the red filter show the clear cell elongation (Figure 9).

An Alamar Blue Assay was performed on days 1, 4, and 6 to evaluate cell proliferation. Cells showed a limited proliferation in the function of time. Moreover, for some samples ( $\beta$-TCP S5 and ATZ 6), there is a decrease in proliferation. In general, cell proliferation was the highest on the B-TCP S11 and ATZ 5 samples. This was also confirmed by live/dead assay (Figures 9 and 10), where more viable cells were seen on both samples. However, the tests performed with Alamar Blue Assay did not show the highest signals for cell proliferation, but there is a sign showing different sensitivity in close relation to the type of patterning performed.

The cells were monitored on different patterned substrates at 1, 4, and 6 days. As seen from the graphs, cells were able to grow in different levels of the scaffold. As a basic tendency, a lower fluorescence signal was determined for the samples treated in the type one regime (Table 1) - the continuous scanning with two diverse velocities and in the cases of pulse selection regime (type II) with low scanning speeds. The results from the Alamar Blue ${ }^{\circledR}$ Assay are given in the form of a graph (Figure 11) - the five different samples of $\beta$-TCP pellets and two ATZ samples treated with different parameters of the fs laser (as given previously in Table 1) were fluorescently monitored on the first, fourth, and sixth day after cell seeding according to a positive and negative control. As expected from these first preliminary cellular results, the different parameters of the fs laser patterning influence MC3T3 cell growth - for example, the highest fluorescent signal is observed in the case of $\beta$-TCP S11, where spot by spot areal scanning by the laser was performed $(\mathrm{N}=1,2,5,10$; $\mathrm{F}=0.61 \mathrm{~J} / \mathrm{cm}^{2}$ ). With increasing fluence ( $\beta$-TCP S10 and S12), at the same scanning mode of the laser, the fluorescent signal decreases for day 1 , day 4 , and day 6 . The results obtained 
in the case of continuous scanning regime are analogical, where the higher fluorescent signal is again observed at the lower fluence applied ( $\beta$-TCP S6).

Another interesting observation is the behavior of seeded ATZ samples. The samples were treated in regime type II, hence, here, the major difference is expressed mainly in the scanning speed, where, at the least velocities, a decrease in the fluorescence signal is monitored and, by increasing the velocity, a drastic increase of the signal for first, fourth, and sixth days is observed-Figure 11.

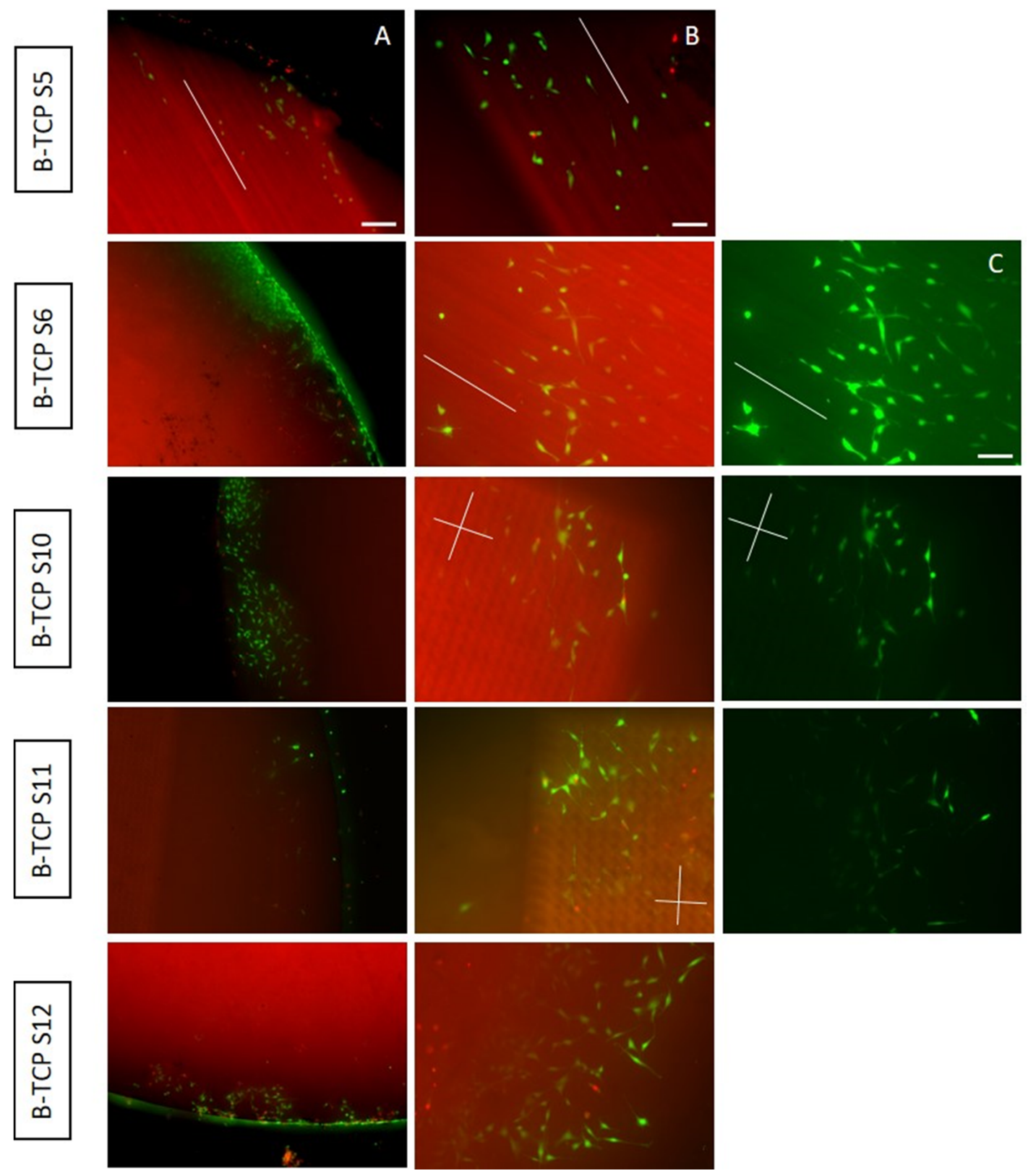

Figure 9. Fluorescence microscopy images of live/dead staining of MC3T3 mouse calvaria cells' distribution 7 days in culture on different B-TCP ceramic laser-patterned surfaces. Living cells stain green, whereas dead cells stain red. The white lines show the lines of the pattern on the samples. (A) Overview images with scale bar of $200 \mu \mathrm{m}$. (B) Detailed images with scale bar of $100 \mu \mathrm{m}$. (C) Detailed images without a red filter clearly show that cells grow following the pattern of the surface (scale bar $100 \mu \mathrm{m}$ ). 

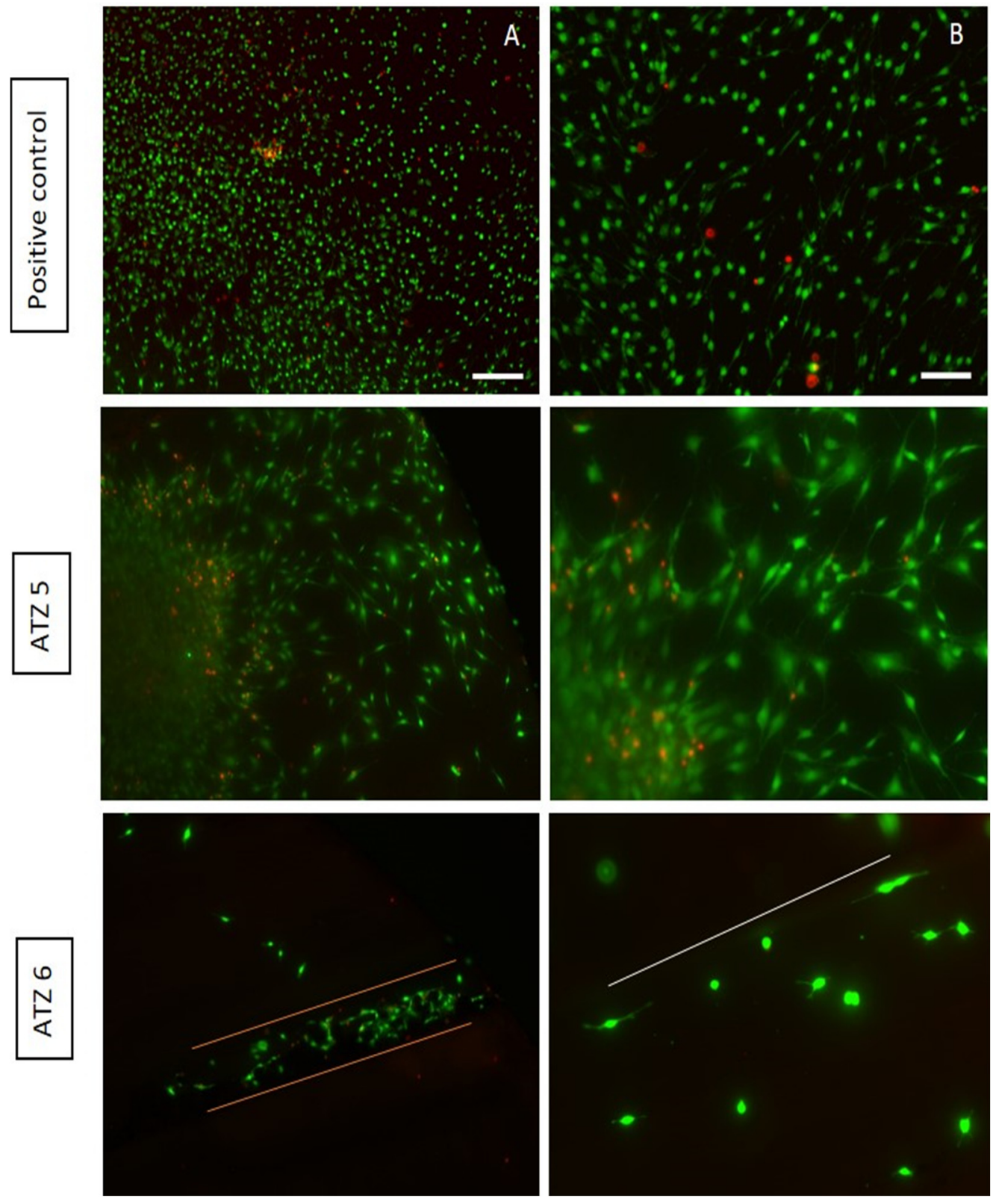

Figure 10. Fluorescence microscopy images of live/dead staining of MC3T3 mouse calvaria cells' distribution 7 days in culture on two different alumina toughened zirconia (ATZ) ceramic laser-patterned surfaces. Living cells stain green, dead cells stain red. The white lines show the lines of the pattern on the samples. Orange lines show the edges of a groove pattern on the surface. For the positive control, staining was performed without the presence of a ceramic material. (A) Overview images with scale bar $200 \mu \mathrm{m}$. (B) Detailed images with scale bar $100 \mu \mathrm{m}$.

These data suggest that, by depositing large amounts of energy into the sample, either by increasing the laser fluence and keeping the least number of applied laser pulses, or by lowering the scanning velocity, we monitor the decrease of cell viability. In summary, as a first preliminary observation, the effect of cell elongation is observed in the case of gentle material treatment mainly related to lower thresholds of laser fluence and selection of $\mathrm{N}$ from 2 to 10 . This fact has a reasonable explanation by the amount of energy deposition into the material and increase of heat accumulation, which is closely related to the type of treatment and, more specifically, strongly dependent on the interplay between laser fluence, scanning speed, and the number of applied laser pulses.

It is expected that, in the process of regeneration of tissue, cells will follow pre-existing ECM microtopography. However, in previous measurements, significantly fewer motile 
cells were detected on patterned substrates. Thus, additional visualization implementing actin staining was performed-Figure 12 .

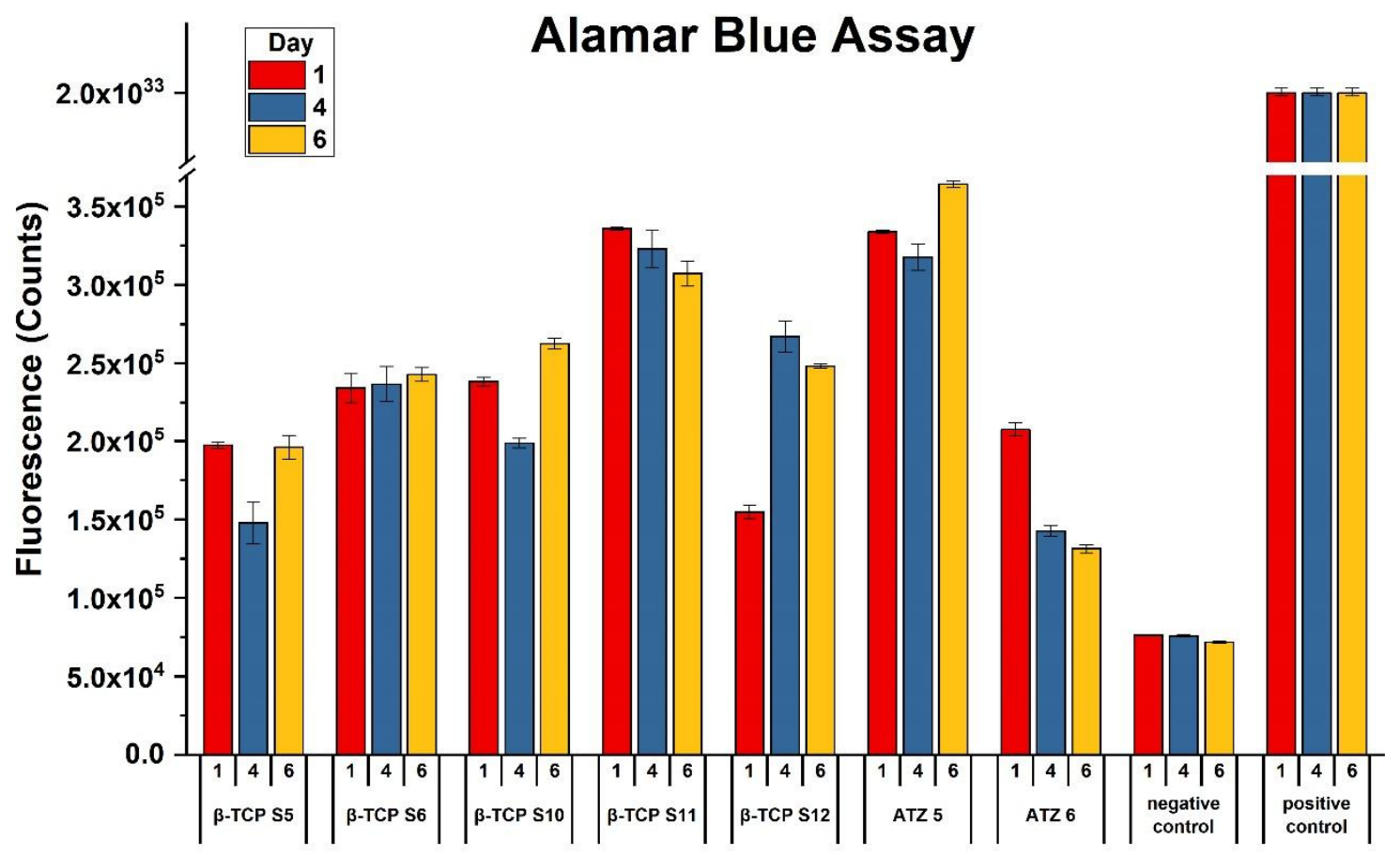

Figure 11. Bar graphs displaying the results of the Alamar Blue Assay on day 1 (red), 4 (blue), and 6 (yellow). The bars display the average data \pm SD on three different days of analysis for all samples and negative control. Positive control values were the same for day 1 , day 4 , and day $6 ; 2.00 \times 10^{33}$ (average) $5.93173 \times 10^{17}$ (SD).
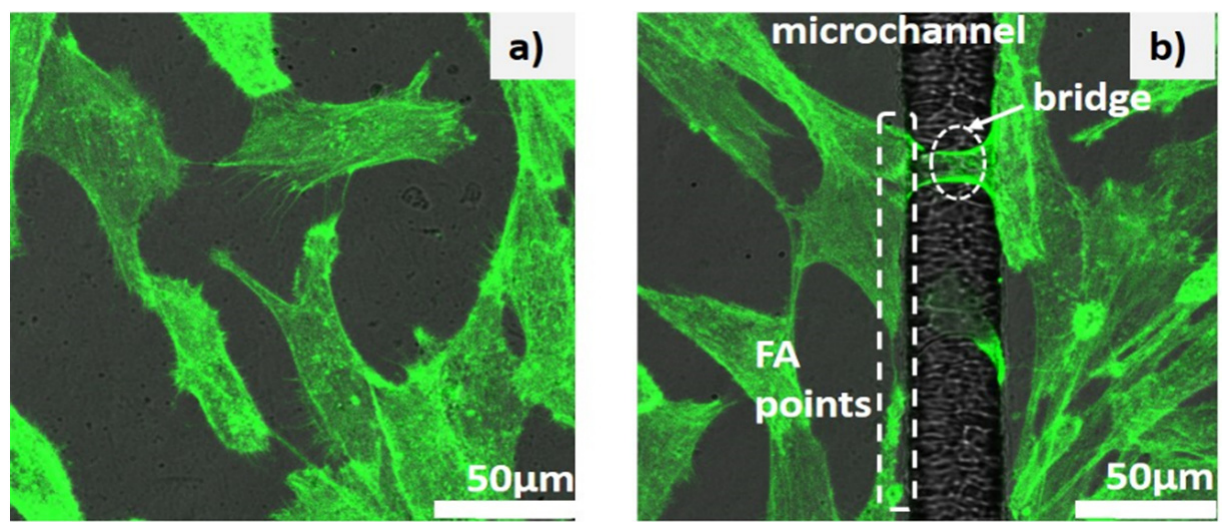

Figure 12. Cell alignment visualized after $48 \mathrm{~h}$ with rhodamine phalloidin for actin staining: (a) cells cultured on control, non-patterned surface and $(\mathbf{b})$ patterned surface $\left(\mathrm{F}=0.61 \mathrm{~J} / \mathrm{cm}^{2}, \mathrm{~V}=3.8 \mathrm{~mm} / \mathrm{s}\right)$, in the form of a microchannel.

The image in Figure $12 \mathrm{~b}$ demonstrates that induced microchannels provide a point of directional adhesion for the generation of focal adhesions towards a concrete direction, thus influencing the cytoskeleton assembly. It is observed that the ridge of the pattern has an important role for controlling cellular cytoskeleton alignment. As a first observation, it is visible from Figure $12 \mathrm{~b}$ that the focal contacts primarily interact with the surrounding edges of the processed microchannels. The cells start to form bridges across the created microchannel by forming cell-to-cell interactions. Thus, cell cytoskeleton rearrangement is triggered by communication with different topographical features of ECM, which in turn mediates cell directional orientation. 
However, further biological studies are planned to be conducted in order to prove the reproducibility of the results.

\section{Discussion}

In the last decade, femtosecond laser processing of biodegradable polymers for application in tissue engineering has been intensively studied by many research groups [54-61]. However, things stand totally different regarding the treatment of bioceramics with ultrashort laser pulses for medical use, as the research is not as extensive [31,60-65]. The works of Thevlek, Hoover, and Park [65-68] clearly outline that $\beta$-TCP is one of the most investigated forms of calcium phosphates to be used in bone tissue regeneration. The group of Tatara et al. [69] describes bioreactor chambers filled with bioceramic granules of $\beta$-TCP and HA and implanted against the ribs in a large-animal model, leading to the generation of a mineralized tissue comparable to bone autografts, while Puttini et al. [70] evaluate the osteoconduction of this ceramic in the calvaria of rats. The ultra-fast laser surface modification method via a selection of different wavelengths and fluence modes of ceramic samples proposed in this paper is a novel approach for micropatterning of the $\beta$-TCP pellets' surface, as it produces a negligible amount of damage, due to the absence of thermal side effects [71,72]. After precise tuning of laser parameters ( $\mathrm{N}$ and $\mathrm{F}$ ), gentle surface patterning of the $\beta$-TCP samples was achieved and cracks, material ejection, and transition to an $\alpha$-TCP form of the material were avoided.

As a general tendency, from this first attempt of biological study, as well as the comparison of cellular spread on the polished $\beta$-TCP sample surface and laser-treated areas, it can be summarized that cellular expansion is more visible on the processed surfaces only in specific laser treatment regimes for both applied laser-patterning methods. It can be interpreted as a tendency that the adhesion points provided by the groove-like topography are favorable to the cell adhesion. The cells change their forms (Figures 10 and 12) in relation to diverse surface roughness; for example, we have an elongation of their form on the samples with lower roughness $(1.3 \mu \mathrm{m})$, which contributes to the elastic force, influencing the focal adhesions of cells. Furthermore, the cells tend to align on the grooves with increasing roughness parameters up to $1.5 \mu \mathrm{m}$ (Table 1), as demonstrated in Figure 9, owing to the contact-guidance alignment. However, on the surfaces with increased width and depth of the surface stripes, the cells do not have enhanced adhesion and proliferation rate, which could probably be attributed to the dimensions of the laser-created structures. This leads us to the conclusion that the size of the patterns is a precondition to the cell orientation. More specifically, the cells demonstrate enhanced sensitivity to micro-structures, whose range is approximately equal to the cellular dimensions.

The group of C. Ruiz-Aguilar [72] reported different morphologies and sizes of synthesized $\beta$-TCP powder such as nanoparticles, nanospheres, nanotubes, irregular shapes with agglomerations, and so on, after elaborate examination with FE-SEM, FTIR, EDX, TEM, surface area, and particle size analysis. Additional texturing of such bioceramic surfaces could significantly improve cell seeding, adhesion, and proliferation and enhance their application in bone tissue engineering [73,74]. This statement is supported by the papers of E. Meurice and M. Lasgorceix, [75,76], which report a high increase of MG63 population growth after fs laser micro-patterning, compared with that on smooth $\beta$-TCP substrates, as well as a tendency of cell elongation along the direction of the grooves in the case of linear patterned surfaces. This technique provides an interesting alternative to conventional surface treatments of calcium phosphates. Ceramic surface topography has an active role in the deposition of hyaluronic-acid-rich ECM-a potential factor in osteoinduction by calcium phosphate bioceramics [77], which makes their clinic application as injectable bone cement or as coatings on implants [78] even more successful.

Laser pre-treatment of the tissue-engineered $\beta$-TCP can be employed to navigate cell motility towards a particular direction. In this way, the growth of future tissue in the desired direction is maintained by the groove-like surface channels created by processing via fs pulses. Such surface functionalization is largely dependent on the surface texture 
and quality. The highly brittle nature of the bioceramic materials makes their topography modification by traditional texturing methods very difficult. Modification of bioceramic substrates could essentially improve the bioactivity properties of bone-engineered scaffolds and could lead to the enhancement of physical, topological, and morphological properties of the $\beta$-TCP ceramic pellets, without additional chemical contamination, which in turn will help cellular "invasion" over the engineered scaffold.

As a future perspective, we plan to optimize further the surface topography, morphology, and wettability of Beta-TCP, in terms of cell culture requirements in relation to surface roughness and structure dimensions. High-magnification SEM morphological studies will be performed in order to evaluate in detail the diverse cells' morphology in respect to a change in surface topography. As an additional step covering the fs laser modified samples with biopolymers, such as chitosan or collagen, which are known for their good cell adhesion activity, could contribute to enhancing the first contact between the cells and the ceramic material. In this way, an improved initial adhesion could be achieved. Atomic layer deposition (ALD) of a thin layer of $\mathrm{ZnO}$ will be performed in order to optimize the antibacterial properties of the surface, thus avoiding pollution of the seeded samples. Functionalization with extracellular active molecules of the samples is also planned. Apart from cell adhesion and viability, more attention will also be paid to metabolic activity on the 7th, 14th, and 28th day of cultivation, and even cell differentiation will be studied.

\section{Conclusions}

We showed experimentally that, under femtosecond laser irradiation, microporous topography modification on the bioceramic surface of $\beta$-TCP pellets was established with high reproducibility. A patterned surface with tunable roughness was demonstrated when a selected set of parameters of femtosecond laser radiation were used. The performed tests with MC3T3 osteoblasts cells demonstrate the influence over cellular dynamics by monitoring a disordered spreading on smooth surfaces and a tendency of elongation along the grooves, suggesting that surface topography could be a key parameter for the cell migration phenomenon. Monitoring the optimization of the laser modification conditions in regard to the unwanted $\beta-\alpha$ transition in combination with the environment-friendly cell conditions, without additional chemical contamination and biochemical changes of the bioceramic, makes femtosecond laser modification a promising technique for $\beta$-TCP optimized integration as a reliable fs-structured osteoblasts environment.

Author Contributions: Conceptualization, A.D.; methodology, A.D.; writing, A.D.; original draft preparation, A.D.; project administration, A.D.; writing, L.A.; original draft preparation, L.A.; software, A.T.; methodology, M.L.; visualization, M.L.; methodology, S.H.; visualization, S.H.; investigation, M.M.; methodology, M.M.; investigation, H.D.; methodology, H.D.; supervision, A.L.; validation, A.L.; investigation, D.A.; investigation, I.B.; supervision, I.B. All authors have read and agreed to the published version of the manuscript.

Funding: This work has received funding from the EUROPEAN UNION'S H2020 research and innovation programme under the Marie Sklodowska-Curie Grant Agreement No. 861138. This research was funded by BULGARIAN NATIONAL SCIENCE FUND (NSF) under grant number No. KP-06-H48/6 (2020-2023), "Development of hybrid functional micro/nanoporous biomaterial scaffolds by ultra-fast laser modification", grant number KP-06-RILA/8 (43192QK), Ultra-short laser-based functionalization of bioceramics and composites 2018-2021.

Institutional Review Board Statement: Not applicable.

Informed Consent Statement: Not applicable.

Data Availability Statement: Data available on request due to restrictions eg privacy or ethical. The data presented in this study are available on request from the corresponding author. The data are not publicly available due to project condition limitations.

Conflicts of Interest: The authors declare no conflict of interest. 


\section{References}

1. World Population Prospects: The 2019 Revision. United Nations DESA/ Population Division. 2019. Available online: https: / / population.un.org/wpp/ (accessed on 20 May 2020).

2. Scheinpflug, J.; Pfeiffenberger, M.; Damerau, A.; Schwarz, F.; Textor, M.; Lang, A.; Schulze, F. Journey into Bone Models: A Review. Genes 2018, 9, 247. [CrossRef]

3. Tozzi, G.; De Mori, A.; Oliveira, A.; Roldo, M. Composite hydrogels for bone regeneration. Materials 2016, 9, 267. [CrossRef]

4. Alaribe, F.N.; Manoto, S.L.; Motaung, S.C.K.M. Scaffolds from biomaterials: Advantages and limitations in bone and tissue engineering. Biologia 2016, 71, 353-366. [CrossRef]

5. Clarke, B. Normal bone anatomy and physiology. Clin. J. Am. Soc. Nephrol. 2008, 3, 131-139. [CrossRef]

6. Terakawa, M. Femtosecond laser processing of biodegradable polymers. Appl. Sci. 2018, 8, 1123. [CrossRef]

7. Dhandayuthapani, B.; Yoshida, Y.; Maekawa, T.; Kumar, D.S. Polymeric Scaffolds in Tissue Engineering Application: A Review. Int. J. Polym. Sci. 2011, 2011, 290602. [CrossRef]

8. Zhang, D.; Wu, X.; Chen, J.; Lin, K. The development of collagen based composite scaffolds for bone regeneration. Bioact. Mater 2018, 3, 129-138. [CrossRef]

9. Teixeira, S.; Monteiro, F.J.; Ferraz, M.P.; Vilar, R.; Eugenio, S. Laser surface treatment of hydroxyapatite for enhanced tissue integration: Surface characterization and osteoblastic interaction studies. J. Biomed. Mater. Res. A 2007, 81, 920-929. [CrossRef]

10. Zhang, F.; Lin, K.; Chang, J.; Lu, J.; Ning, C. Spark plasma sintering of macroporous calcium phosphate scaffolds from nanocrystalline powders. J. Eur. Ceram. Soc. 2008, 28, 539-545. [CrossRef]

11. Miranda, P.; Saiz, E.; Gryn, K.; Tomsia, A.P. Sintering and robocasting of $\beta$-tricalcium phosphate scaffolds for orthopaedic applications. Acta Biomater. 2006, 2, 457-466. [CrossRef]

12. Perera, F.H.; Martínez-Vázquez, F.J.; Miranda, P.; Ortiz, A.L.; Pajares, A. Clarifying the effect of sintering conditions on the microstructure and mechanical properties of $\beta$-tricalcium phosphate. Ceram. Int. 2010, 36, 1929-1935. [CrossRef]

13. Lu, J.; Descamps, M.; Dejou, J.; Koubi, G.; Hardouin, P.; Lemaitre, J.; Proust, J.-P. The biodegradation mechanism of calcium phosphate biomaterials in bone. J. Biomed. Mater. Res. 2002, 63, 408-412. [CrossRef]

14. Kondo, N.; Ogose, A.; Tokunaga, K.; Umezu, H.; Arai, K.; Kudo, N.; Hoshino, M.; Inoue, H.; Irie, H.; Kuroda, K. Osteoinduction with highly purified $\beta$-tricalcium phosphate in dog dorsal muscles and the proliferation of osteoclasts before heterotopic bone formation. Biomaterials 2006, 27, 4419-4427. [CrossRef]

15. Ogose, A.; Kondo, N.; Umezu, H.; Hotta, T.; Kawashima, H.; Tokunaga, K.; Ito, T.; Kudo, N.; Hoshino, M.; Gu, W. Histological assessment in grafts of highly purified beta-tricalcium phosphate (OSferion $®$ ) in human bones. Biomaterials 2006, 27, 1542-1549. [CrossRef]

16. Mirtchi, A.A.; Lemaître, J.; Munting, E. Calcium phosphate cements: Study of the $\beta$-tricalcium phosphate-dicalcium phosphatecalcite cements. Biomaterials 1990, 11, 83-88. [CrossRef]

17. Mirtchi, A.A.; Lemaître, J.; Munting, E. Calcium phosphate cements: Effect of fluorides on the setting and hardening of $\beta$-tricalcium phosphate-dicalcium phosphate-calcite cements. Biomaterials 1991, 12, 505-510. [CrossRef]

18. Lemaître, J.; Munting, E.; Mirtchi, A.A. Setting, hardening and resorption of calcium phosphate ionic cements. Rev. Stomatol. Chir. Maxillofac. 1992, 93, 163-165.

19. Ohura, K.; Bohner, M.; Hardouin, P.; Lemaître, J.; Pasquier, G.; Flautre, B. Resorption of, and bone formation from, new $\beta$-tricalcium phosphate-monocalcium phosphate cements: An in vivo study. J. Biomed. Mater. Res. 1996, 30, 193-200. [CrossRef]

20. Lecomte, A.; Gautier, H.; Bouler, J.M.; Gouyette, A.; Pegon, Y.; Daculsi, G.; Merle, C. Biphasic calcium phosphate: A comparative study of interconnected porosity in two ceramics. J. Biomed. Mater. Res. B Appl. Biomater. 2008, 84, 1-6. [CrossRef] [PubMed]

21. Tancret, F.; Bouler, J.M.; Chamousset, J.; Minois, L.M. Modelling the mechanical properties of microporous and macroporous biphasic calcium phosphate bioceramics. J. Eur. Ceram. Soc. 2006, 26, 3647-3656. [CrossRef]

22. Bouler, J.M.; Trecant, M.; Delecrin, J.; Royer, J.; Passuti, N.; Daculsi, G. Macroporous biphasic calcium phosphate ceramics: Influence of five synthesis parameters on compressive strength. J. Biomed. Mater. Res. 1996, 32, 603-609. [CrossRef]

23. Wang, J.; Chen, W.; Li, Y.; Fan, S.; Weng, J.; Zhang, X. Biological evaluation of biphasic calcium phosphate ceramic vertebral laminae. Biomaterials 1998, 19, 1387-1392. [CrossRef]

24. Daculsi, G. Biphasic calcium phosphate concept applied to artificial bone, implant coating and injectable bone substitute. Biomaterials 1998, 19, 1473-1478. [CrossRef]

25. Daculsi, G.; Weiss, P.; Bouler, J.M.; Gauthier, O.; Millot, F.; Aguado, E. Biphasic calcium phosphate/hydro soluble polymer composites: A new concept for bone and dental substitution biomaterials. Bone 1999, 25, 59-61. [CrossRef]

26. Le Geros, R.Z.; Lin, S.; Rohanizadeh, R.; Mijares, D.; Le Geros, J.P. Biphasic calcium phosphate bioceramics: Preparation, properties and applications. J. Mater. Sci. Mater. Med. 2003, 14, 201-209. [CrossRef]

27. Daculsi, G.; Laboux, O.; Malard, O.; Weiss, P. Current state of the art of biphasic calcium phosphate bioceramics. J. Mater. Sci. Mater. Med. 2003, 14, 195-200. [CrossRef]

28. Alam, I.; Asahina, I.; Ohmamiuda, K.; Enomoto, S. Comparative study of biphasic calcium phosphate ceramics impregnated with rhBMP-2 as bone substitutes. J. Biomed. Mater. Res. 2001, 54, 129-138. [CrossRef]

29. Daculsi, G. Biphasic calcium phosphate granules concept for injectable and mouldable bone substitute. Adv. Sci. Technol. 2006, 49, 9-13. [CrossRef]

30. Dorozhkin, S. Calcium Orthophosphates in Nature, Biology and Medicine. Materials 2009, 2, 399-498. [CrossRef] 
31. Lasgorceix, M.; Ott, C.; Boilet, L.; Hocquet, S.; Leriche, A.; Asadian, M.; De Geyter, N.; Declercq, H.; Lardot, V.; Cambier, F. Micropatterning of beta tricalcium phosphate bioceramic surfaces, by femtosecond laser, for bone marrow stem cells behaviour assessment. Mater. Sci. Eng. C Mater. Biol. Appl. 2019, 95, 371-380. [CrossRef] [PubMed]

32. Amani, H.; Arzaghi, H.; Bayandori, M.; Dezfuli, A.S.; Pazoki-Toroudi, H.; Shafiee, A.; Moradi, L. Controlling Cell Behavior through the Design of Biomaterial Surfaces: A Focus on Surface Modification Techniques. Adv. Mater. Interfaces 2019, 6, 1900572. [CrossRef]

33. Ermis, M.; Antmen, E.; Hasirci, V. Micro and Nanofabrication methods to control cell-substrate interactions and cell behavior: A review from the tissue engineering perspective. Bioact. Mater. 2018, 3, 355-369. [CrossRef]

34. Faria, D.; Madeira, S.; Buciumeanu, M.; Silva, F.S.; Carvalho, O. Novel laser textured surface designs for improved zirconia implants performance. Mater. Sci. Eng. C 2020, 108, 110390. [CrossRef]

35. Biswas, S.; Karthikeyan, A.; Kietzig, A. Effect of Repetition Rate on Femtosecond Laser-Induced Homogenous Microstructures. Materials 2016, 9, 1023. [CrossRef] [PubMed]

36. Sima, L.E.; Bonciu, A.; Baciu, M.; Anghel, I.; Dumitrescu, L.N.; Rusen, L.; Dinca, V. Bioinstructive Micro-Nanotextured Zirconia Ceramic Interfaces for Guiding and Stimulating an Osteogenic Response In Vitro. Nanomaterials 2020, 10, 2465. [CrossRef]

37. Kaur, G.; Dufour, J.M. Cell lines: Valuable tools or useless artifacts. Spermatogenesis 2012, 2, 1-5. [CrossRef]

38. Maqsood, M.I.; Matin, M.M.; Bahrami, A.R.; Ghasroldasht, M.M. Immortality of cell lines: Challenges and advantages of establishment. Cell Biol. Int. 2013, 37, 1038-1045. [CrossRef]

39. Pastor, D.M.; Poritz, L.S.; Olson, T.L.; Kline, C.L.; Harris, L.R.; Koltun, W.A.; Chinchilli, V.M.; Irby, R.B. Primary cell lines: False representation or model system? a comparison of four human colorectal tumors and their coordinately established cell lines. Int. J. Clin. Exp. Med. 2010, 3, 69-83.

40. Pamies, D.; Bal-Price, A.; Chesné, C.; Coecke, S.; Dinnyes, A.; Eskes, C.; Grillari, R.; Gstraunthaler, G.; Hartung, T.; Jennings, P.; et al. Advanced Good Cell Culture Practice for human primary, stem cell-derived and organoid models as well as microphysiological systems. ALTEX 2018, 35, 353-378. [CrossRef] [PubMed]

41. Nasello, G.; Alamán-Díez, P.; Schiavi, J.; Pérez, M.Á.; McNamara, L.; García-Aznar, J.M. Primary Human Osteoblasts Cultured in a 3D Microenvironment Create a Unique Representative Model of Their Differentiation Into Osteocytes. Front. Bioeng. Biotechnol. 2020, 8, 336. [CrossRef] [PubMed]

42. Panseri, S.; Montesi, M.; Hautcoeur, D.; Dozio, S.; Chamary, S.; De Barra, E.; Tampieri, A.; Leriche, A. Bone-like ceramic scaffolds designed with bioinspired porosity induce a different stem cell response. J. Mater. Sci. Mater. Med. 2021, 32, 1-12. [CrossRef]

43. De Zanet, A.; Casalegno, V.; Salvo, M. Laser surface texturing of ceramics and ceramic composite materials-A review. Ceram. Int. 2020, 47, 7307-7320. [CrossRef]

44. Xing, Y.; Luo, C.; Wan, Y.; Huang, P.; Wu, Z.; Zhang, K. Formation of bionic surface textures composed by micro-channels using nanosecond laser on Si3N4-based ceramics. Ceram. Int. 2021, in press. [CrossRef]

45. Cui, J.; Gong, Z.; Rao, P. Effect of molten zone ablated by femtosecond laser on fracture toughness of oxide ceramics. J. Eur. Ceram. Soc. 2018, 38, 2440-2444. [CrossRef]

46. Aizawa, T.; Inohara, T. Pico- and Femtosecond Laser Micromachining for Surface Texturing. In Micromachining; IntechOpen: London, UK, 2019. [CrossRef]

47. Ackerl, N.; Bork, A.H.; Hauert, R.; Müller, E.; Rottmar, M. Rationally designed ultra-short pulsed laser patterning of zirconia-based ceramics tailored for the bone-implant interface. Appl. Surf. Sci. 2021, 545, 149020. [CrossRef]

48. Daskalova, A.; Angelova, L.; Carvalho, A.; Trifonov, A.; Nathala, C.; Monteiro, F.; Buchvarov, I. Effect of surface modification by femtosecond laser on zirconia based ceramics for screening of cell-surface interaction. Appl. Surf. Sci. 2020, 513, 145914. [CrossRef]

49. Boilet, L.; Descamps, M.; Rguiti, E.; Tricoteaux, A.; Lu, J.; Petit, F.; Lardot, V.; Cambier, F.; Leriche, A. Processing and properties of transparent hydroxyapatite and b-tricalcium phosphate obtained by HIP process. Ceram. Int. 2013, 39, 283-288. [CrossRef]

50. Ryu, H.-S.; Hong, K.S.; Lee, J.-K.; Kim, D.J.; Lee, J.H.; Chang, B.-S.; Lee, D.-h.; Lee, C.-K.; Chung, S.-S. Magnesia-doped HA/ $\beta$-TCP ceramics and evaluation of their biocompatibility. Biomaterials 2004, 25, 393-401. [CrossRef]

51. Martinez, I.; Velasquez, P.; Meseguer-Olmo, L.; Bernabeu-Esclapez, A.; De Aza, P. Preparation and characterization of novel bioactive $\alpha$-tricalcium phosphate doped with dicalcium silicate ceramics. Mater. Sci. Eng. C Mater. 2012, 32, 878-886. [CrossRef]

52. Yuan, H.; De Bruijn, J.; Li, Y.; Feng, J.; Yang, Z.; De Groot, K.; Zhang, X. Bone formation induced by calcium phosphate ceramics in soft tissue of dogs: A comparative study between porous $\alpha$-TCP and $\beta$-TCP. J. Mater. Sci. Mater. Med. 2001, 12, 7-13. [CrossRef] [PubMed]

53. Sariibrahimoglu, K.; Wolke, J.G.; Leeuwenburgh, S.C.; Yubao, L.; Jansen, J.A. Injectable biphasic calcium phosphate cements as a potential bone substitute. J. Biomed. Mater. Res. B. Appl. Biomater. 2014, 102, 415-422. [CrossRef]

54. Gaspard, S.; Oujja, M.; de Nalda, R.; Abrusci, C.; Catalina, F.; Bañares, L.; Lazare, S.; Castillejo, M. Nanofoaming in the surface of biopolymers by femtosecond pulsed laser irradiation. Appl. Surf. Sci. 2007, 254, 117-1184. [CrossRef]

55. Gaspard, S.; Forster, M.; Huber, C.; Zafiu, C.; Trettenhahn, G.; Kautek, W.; Castillejo, M. Femtosecond laser processing of biopolymers at high repetition rate. Phys. Chem. Chem. Phys. 2008, 10, 6174-6181. [CrossRef]

56. Gaspard, S.; Oujja, M.; de Nalda, R.; Castillejo, M.; Bañares, L.; Lazare, S.; Bonneau, R. Nanofoaming dynamics in biopolymers by femtosecond laser irradiation. Appl. Phys. A 2008, 93, 209-213. [CrossRef]

57. Oujja, M.; Pérez, S.; Fadeeva, E.; Koch, J.; Chichkov, B.N.; Castillejo, M. Three dimensional microstructuring of biopolymers by femtosecond laser irradiation. Appl. Phys. Lett. 2010, 95, 263703. [CrossRef] 
58. Li, H.; Wong, Y.S.; Wen, F.; Ng, K.W.; Ng, G.K.; Venkatraman, S.S.; Boey, F.Y.; Tan, L.P. Human mesenchymal stem-cell behaviour on direct laser micropatterned electrospun scaffolds with hierarchical structures. Macromol. Biosci. 2013, 13, 299-310. [CrossRef]

59. Ortiz, R.; Moreno-Flores, S.; Quintana, I.; Vivanco, M.; Sarasua, J.R.; Toca-Herrera, J.L. Ultra-fast laser microprocessing of medical polymers for cell engineering applications. Mater. Sci. Eng. C Mater. Biol. Appl. 2014, 1, 241-250. [CrossRef]

60. Castillejo, M.; Rebollar, E.; Oujja, M.; Sanz, M.; Selimis, A.; Sigletou, M.; Psycharakis, S.; Ranella, A.; Fotakis, C. Fabrication of porous biopolymer substrates for cell growth by UV laser: The role of pulse duration. Appl. Surf. Sci. 2012, 258, 8919-8927. [CrossRef]

61. Jun, I.; Chung, Y.; Heo, Y.; Han, H.; Park, J.; Jeong, H.; Lee, H.; Lee, Y.B.; Kim, Y.-C.; Seok, H.-K.; et al. Creating hierarchical topographies on fibrous platforms using femtosecond laser ablation for directing myoblasts behaviour. ACS Appl. Mater. Interfaces 2016, 8, 3407-3417. [CrossRef] [PubMed]

62. Denry, I.; Kuhn, L.T. Design and characterization of calcium phosphate ceramic scaffolds for bone tissue engineering. Dent. Mater. 2016, 32, 43-53. [CrossRef] [PubMed]

63. Samavedi, S.; Whittington, A.R.; Goldstein, A.S. Calcium phosphate ceramics in bone tissue engineering: A review of properties and their influence on cell behaviour. Acta Biomater. 2013, 9, 8037-8045. [CrossRef]

64. Sun, J.; Tang, J.; Ding, J. Cell orientation on a stripe-micropatterned surface. Chin. Sci.Bull. 2009, 54, 3154-3159. [CrossRef]

65. Tevlek, A.; Hosseinian, P.; Ogutcu, C.; Turk, M.; Aydin, H.M. Bi-layered constructs of poly (glycerol-sebacate)- $\beta$-tricalcium phosphate for bone-soft tissue interface applications. Mater. Sci. Eng. C 2017, 72, 316-324. [CrossRef] [PubMed]

66. Hoover, S.; Tarafder, S.; Bandyopadhyay, A.; Bose, S. Silver doped resorbable tricalcium phosphate scaffolds for bone graft applications. Mater. Sci. Eng. C 2017, 79, 763-769. [CrossRef] [PubMed]

67. Park, J.; Lee, S.J.; Jo, H.H.; Lee, J.H.; Kim, W.D.; Lee, J.Y.; Park, S.A. Fabrication and characterization of 3D-printed bone-like $\beta$-tricalcium phosphate/polycaprolactone scaffolds for dental tissue engineering. J. Ind. Eng. Chem. 2017, 46, 175-181. [CrossRef]

68. Gamaly, E. The physics of ultra-short laser interaction with solids at non-relativistic intensities. Phys. Rep. 2011, 508, 91-243. [CrossRef]

69. Tatara, A.M.; Koons, G.L.; Watson, E.; Piepergerdes, T.C.; Shah, S.R.; Smith, B.T.; Shum, J.; Melville, J.C.; Hanna, I.A.; Demian, N.; et al. Biomaterials- aided mandibular reconstruction using in vivo bioreactors. Proc. Natl. Acad. Sci. USA 2019, 116, 6954-6963. [CrossRef]

70. Puttini, I.D.O.; Poli, P.P.; Maiorana, C.; de Vasconcelos, I.R.; Schmidt, L.E.; Colombo, L.T.; Hadad, H.; Santos, G.M.D.; de Carvalho, P.S.P.; Souza, F.Á. Evaluation of osteoconduction of biphasic calcium phosphate ceramic in the calvaria of rats: Microscopic and histometric analysis. J. Funct. Biomater. 2019, 10, 7. [CrossRef]

71. Narayan, R.J.; Jin, C.; Doraiswamy, A.; Mihailescu, I.N.; Jelinek, M.; Ovsianikov, A.; Chichkov, B.; Chrisey, D.B. Laser processing of advanced bioceramics. Adv. Eng. Mater. 2007, 9, 83. [CrossRef]

72. Ruiz-Aguilar, C.; Olivares-Pinto, U.; Aguilar-Reyes, E.A.; López-Juárez, R.; Alfonso, I. Characterization of $\beta$-tricalcium phosphate powders synthesized by sol-gel and mechanosynthesis. Boletín Soc. Española Cerámica Vidr. 2018, 57, 213-220. [CrossRef]

73. Bohner, M.; Baroud, G.; Bernstein, A.; Döbelin, N.; Galea, L.; Hesse, B.; Heuberger, R.; Meille, S.; Michel, P.; von Rechenberg, B.; et al. Characterization and distribution of mechanically competent mineralized tissue in micropores of $\beta$ - tricalcium phosphate bone substitutes. Mater. Today 2017, 20, 106-115. [CrossRef]

74. Zhu, Y.; Zhang, K.; Zhao, R.; Ye, X.; Chen, X.; Xiao, Z.; Yang, X.; Zhu, X.; Zhang, K.; Fan, Y.; et al. Bone regeneration with micro/nano hybrid- structured biphasic calcium phosphate bioceramics at segmental bone defect and the induced immunoregulation of MSCs. Biomaterials 2017, 147, 133-144. [CrossRef]

75. Meurice, E.; Bouchart, F.; Hornez, J.C.; Leriche, A.; Hautcoeur, D.; Lardot, V.; Cambier, F.; Fernandes, M.H.; Monteiro, F. Osteoblastic cells colonization inside beta-TCP macroporous structures obtained by ice-templating. J. Eur. Ceram. Soc. 2016, 36, 2895-2901. [CrossRef]

76. Lasgorceix, M.; Grenho, L.; Fernandes, M.H.; Ott, C.; Boilet, L.; Leriche, A.; Monteiro, F.; Cambier, F.; Hocquet, S. Femtosecond laser impact on calcium phosphate bioceramics assessed by micro-Raman spectroscopy and osteoblastic behaviour. J. Eur. Ceram. Soc. 2018, 38, 5545-5553. [CrossRef]

77. Groen, N.; Yuan, H.; Hebels, D.G.; Koçer, G.; Mbuyi, F.; LaPointe, V.; Truckenmüller, R.; van Blitterswijk, C.A.; Habibović, P.; de Boer, J. Linking the transcriptional landscape of bone induction to biomaterial design parameters. Adv. Mater. 2017, 29, 1603259. [CrossRef] [PubMed]

78. Tang, Z.; Li, X.; Tan, Y.; Fan, H.; Zhang, X. The material and biological characteristics of osteoinductive calcium phosphate ceramics. Regen. Biomater. 2018, 5, 43-59. [CrossRef] [PubMed] 